\title{
Board committees and non-financial information assurance services
}

\author{
Isabel-María García-Sánchez ${ }^{1}$ (D) Nicola Raimo ${ }^{2}$ - Víctor Amor-Esteban ${ }^{3}$. \\ Filippo Vitolla ${ }^{2}$
}

Accepted: 19 November 2021 / Published online: 17 December 2021

(c) The Author(s) 2021

\begin{abstract}
The objective of this study is to examine the role that the specialized committees, created within the board of directors, and the auditor play in relation to the hiring of a non-financial information assurance service and in relation to the choices of the assurance provider for such non-financial information. Specifically, this study analyses the effect of the independence and specialisation of the audit committee, the existence of a CSR committee, and the reputation of the financial auditor associated with its classification as Big4. The results indicate that those responsible for financial information do not show interest in contracting an assurance service, especially if it is realized by an accountant provider, except that the information is standardised according to the Global Reporting Initiative guidelines and the contracted service is comparable to the financial audit standards, has assurance for a reasonable/high level, and is carried out according to the ISAE3000 standard.
\end{abstract}

Keywords Non-financial information · Assurance $\cdot$ Audit committee $\cdot$ CSR committee $\cdot$ Agency theory

Isabel-María García-Sánchez

lajefa@usal.es

Nicola Raimo

raimo@lum.it

Víctor Amor-Esteban

vamor@usal.es

Filippo Vitolla

vitolla@lum.it

1 Departamento de Administración y Economía de la Empresa and Instituto Multidisciplinar de Empresa (IME), Universidad de Salamanca, Campus Miguel de Unamuno, Edificio FES, 37007 Salamanca, Spain

2 Department of Management, Finance and Technology of the LUM University, Casamassima, Italy

3 Departamento de Estadística, Universidad de Salamanca, Campus Miguel de Unamuno, 37007 Salamanca, Spain 


\section{Introduction}

Companies are receiving increasing pressure from stakeholders to demonstrate that they operate sustainably and incorporate sustainable development and sustainable actions into their corporate identity (Al-Shaer \& Zaman, 2018; Amran et al., 2014; Dutta et al., 2012; García-Sánchez et al., 2020; Jizi, 2017; Raimo et al., 2019; Vitolla et al., 2019a). Therefore, the commitments to sustainability, sustainable development, and transparency are at the top of the corporate agenda (Al-Shaer \& Zaman, 2018; Nicolò et al., 2021; Vitolla et al., 2021). In developing sustainability strategies, companies are called upon to make decisions and allocate resources to the different sustainable initiatives and actions capable of guaranteeing competitive advantages (Arena et al., 2018; Yadav et al., 2016). Awareness of the reputational and financial risks associated with sustainability issues (Birkey et al., 2016; Darnall et al., 2009; De Villiers et al., 2011; GRI, 2013; KPMG, 2014; Moroney et al., 2012; Simnett et al., 2009a) is making the supervision of sustainability practices and reporting a priority for companies, which, in light of this, are expanding the responsibility of governance mechanisms to address the needs and expectations of stakeholders (Al-Shaer \& Zaman, 2018; Vitolla et al., 2019b).

In this regard, assurance represents an important means of increasing the reliability and credibility of non-financial information, just as occurs for external auditing of financial reporting (Cuadrado-Ballesteros et al., 2017; Martínez-Ferrero \& García-Sánchez, 2017a; Simnett et al., 2009a). Attention to the assurance of non-financial information has grown considerably in recent years, as demonstrated by Kolk and Perego (2010), who highlighted that about $40 \%$ of CSR reports issued by large international companies are assured by a third party. The growing adoption of non-financial information assurance by international companies has also attracted the attention of the academic world. The contributions on the issue of assurance of non-financial information present in the literature, as suggested by Cohen and Simnett (2015), have mainly examined the process and trends (Deegan et al., 2006; O’Dwyer \& Owen, 2007; Wallage, 2000); firm-level, country-level, and industry-level drivers (Casey \& Grenier, 2015; Cho et al., 2014; Mock et al., 2007; Peters \& Romi, 2015; Simnett et al., 2009); and financial and non-financial effects of this practice (Cheng et al., 2015; Cho et al., 2014; Pflugrath et al., 2011).

However, Cohen and Simnett (2015) in their research agenda stressed that the issue of non-financial information assurance remains little explored and that further efforts are needed by academics to better understand this phenomenon. In this regard, Liao et al. (2018) underlined the importance of examining the role of corporate governance mechanisms in the non-financial information assurance policies. This study responds to this need and aims to contribute to the knowledge relating to the drivers of the non-financial information assurance through the analysis of the role of the board committees in assurance services.

The board of directors represents the corporate governance mechanism aimed at monitoring, guiding, and controlling companies. It makes the main strategic 
and operational decisions considering the needs of shareholders and stakeholders (Jo \& Harjoto, 2012; Raimo et al., 2020). A well-governed board should, on the one hand, actively promote the sharing of values and behaviours regarding compliance with the law, external relations, and social and environmental commitments and, on the other hand, ensure the quality and credibility of disclosure (Liao et al., 2018). Therefore, non-financial disclosure policies (also in relation to assurance) are a direct result of the nature of the board and its subcommittees.

In particular, it is expected that the audit committees, now widespread in international companies, are expected to exercise greater supervision over financial and non-financial information (Al-Shaer \& Zaman, 2018; EY, 2014; ICAA, 2014; Raimo et al., 2021a; Trotman \& Trotman, 2015). In fact, they are increasingly concerned not to mislead stakeholders and are interested in guaranteeing the quality and credibility of the information disclosed (Al-Shaer \& Zaman, 2018). In this regard, Trotman and Trotman (2015) emphasise that audit committees are concerned about non-financial disclosure and increasingly monitor its accuracy. The presence of a CSR committee also shows the commitment of companies to social and environmental issues and their willingness to manage conflicts between different groups of stakeholders (Baalouch et al., 2019). The presence of this body represents a signal of the company's orientation towards social and environmental accountability, which includes adequate communication with external stakeholders (Liao et al., 2015). In this regard, Peters and Romi (2012) underline how the presence of this body helps companies to evaluate the disclosure processes and affects their quality. The board and its subcommittees can affect the quality and credibility of the disclosure also through the choice of the auditing firm. In fact, according to Al-Rassas and Kamardin (2016), external monitoring mechanisms such as an external auditing firm are supposed to improve the quality and credibility of the information disclosed by companies. In this perspective, the assignment of financial information assurance to an important auditing firm could also have repercussions on the assurance of nonfinancial information.

In light of this, it is interesting to examine whether the board committees will influence the assurance of non-financial information and the choice of the assurance provider for such types of information. However, despite the relevance of the topic and the close relationship between board committees and assurance policies, these topics are still unexplored in the literature. In this sense, the objective of this study is to analyse the effect of board committees and the reputation of the financial auditor on the decision of companies to obtain assurance of non-financial information and on assurance provider choices. For this purpose, a sample of 6454 international companies, with 44,282 observations for the period 2011-2017, was used. The results evidence that the quality parameters that currently characterise the verification service diverge notably from financial auditing practices. In this sense, both the audit committee and the CSR committee, as well as the financial auditor, only promote the contracting of these services for a reasonable level of assurance in accordance with the ISAE3000 standard, being a sine qua non requirement that companies disclose standardised information according to the global reporting initiative (GRI) guidelines. In addition, we observed that these corporate mechanisms avoid to hire an audit firm like an assurance provider. 
The reminder of this study is organized as follows: Sect. 2 presents the literature review, while Sect. 3 introduces the theoretical background and develops hypotheses. Section 4 examines the research methodology. Section 5 presents and discusses the results. Finally, Sect. 6 draws conclusions.

\section{Literature review}

The dissemination of non-financial information has significant consequences for issuing companies (Chen et al., 2016a; Dhaliwal et al., 2011). Positive information related to social and environmental aspects can signal a high level of managerial integrity and a strong responsibility of the company towards all stakeholders, favouring a reduction in operating and default risks (Chen et al., 2016a; Deng et al., 2013; Dhaliwal et al., 2012; Hoi et al., 2013). A wide dissemination of nonfinancial information can help the firm in building a good reputation, which in turn can guarantee benefits related to obtaining a competitive advantage in the product, labour and capital markets (Choi \& Wang, 2009; Deng et al., 2013). Furthermore, a wide dissemination of non-financial information can also lead to a change in internal management practices by creating incentives for firms to better manage relations with investors, employees, regulators, suppliers, customers and civil society (Chen et al., 2016a).

However, non-financial information only gains value for stakeholders when they consider it credible (Odriozola \& Baraibar-Diez, 2017). This circumstance poses important challenges for firms that are called upon to guarantee a certain credibility of non-financial information in the eyes of stakeholders (Odriozola \& BaraibarDiez, 2017). In this regard, firms must try to fill the credibility gap (Odriozola \& Baraibar-Diez, 2017), that is, the situation in which the information provided is not believed or considered reliable by the stakeholders. Some scholars have found a possible solution in assurance, understood as an important voluntary tool to ensure credibility of non-financial information (Adams \& Evans, 2004; Dando \& Swift, 2003; Zorio et al., 2013). In this regard, the choice of important assurance providers also represents a solution to ensure credibility of non-financial information (RuizBarbadillo \& Martínez-Ferrero, 2020). Assurance policies are thus becoming more and more relevant (O'Dwyer \& Owen, 2005) as they translate into greater transparency, quality and trust in disseminated information (Adams \& Evans, 2004; Cho et al., 2014; Simnett et al., 2009b) and could guarantee important benefits to firms (Martínez-Ferrero \& García-Sánchez, 2018) such as a reduction in the cost of equity (Casey \& Grenier, 2015), a restatement of previously reported non-financial information (Michelon et al., 2019), an improvement in the environmental standing of firms (Birkey et al., 2016) and a greater likelihood of inclusion in the Dow Jones sustainability index (Clarkson et al., 2019).

In line with the objectives of this study, the literature review focuses firstly on studies examining the drivers of assurance of non-financial information and secondly on studies that analyse the determinants of assurance provider choices.

As regards the drivers of assurance of non-financial information, one group of studies examined industry-level drivers. In this regard, Mock et al. (2007) showed 
that companies operating in environmentally sensitive sectors such as oil, utilities, and mining are more likely to provide assured sustainability reports. Simnett, Nugent, et al. (2009) obtained similar results. In fact, they found that companies highly exposed to social and environmental risks, such as those operating in the mining, utilities, manufacturing, and finance industries, have a greater need to ensure credibility of their sustainability reports and, therefore, make more use of assurance activities. Cho et al. (2014) showed that belonging to highly polluting sectors as well as the finance industry has a positive effect on the choice to obtain assurance on sustainability reports. In contrast, Casey and Grenier (2015) found that US firms operating in the utilities and finance industries, despite facing significant environmental and social risks, are not more likely to provide assured sustainability reports.

A second group of studies instead examined country-level drivers. In this regard, Kolk and Perego (2010) found that firms located in countries with weak governance enforcement mechanisms, civil law systems, and higher pressure towards CSR due to public policy are more likely to provide assured sustainability reports. Besides, Li et al. (2013) added that legal environment, social trust, and media scrutiny significantly affect the propensity of CSR assurance.

Finally, another group of studies examined firm-level drivers. In this regard, Casey and Grenier (2015) found that highly leveraged firms are less likely to obtain CSR assurance. According to Li et al. (2013), in addition to the leverage ratio, the firm size also influences the propensity of CSR assurance. With reference to the aspects relating to governance mechanisms, Liao et al. (2018) found that board size and board gender diversity positively affect the propensity of CSR assurance. They highlighted that the separation of CEO and chairman positions also has a positive influence on the CSR assurance activities. Moreover, Al-Shaer and Zaman (2018) added that audit committee characteristics have an effect, additional to that of the board of directors and the presence of a CSR committee, on voluntary CSR assurance. Finally, Peters and Romi (2015) examined the role of the chief sustainability officer, finding that its presence is positively associated with CSR assurance services, and that this relationship increases when the chief sustainability officer has sustainability expertise.

With regard to the determinants of assurance provider choices, a first important line of literature has identified the quality of the assurer as one of the main drivers (Green et al., 2017). In this regard, according to DeAngelo (1981), the selection criteria relating to quality can be traced back to the assurer's competence to identify errors and independence to report them. According to Duff (2009) the relevant aspects of the assurer include competence, relationship, independence and service qualities. However, the quality of the assurer is not the only driver. In fact, according to the literature, the choice of assurance provider is also influenced by client features (Bedard et al., 2000; Citron \& Manalis, 2001; Knechel et al., 2008), significant stakeholders (Pong \& Kita, 2006), and the level of competitors in the same industry (Kwon, 1996). In addition, some scholars have identified in the characteristics of the board of directors (Beasley \& Petroni, 2001) and audit committee (Abbott \& Parker, 2000; Lennox \& Park, 2007) other elements capable of influencing assurance provider choices. 
The literature review carried out shows limited attention to governance aspects in the context of the drivers of non-financial information assurance and the determinants of assurance provider choices. This study therefore aims to fill these important gaps by analysing the role of board committees.

\section{Theory and research hypotheses}

As regards the different types of determinants, this study focuses on the analysis of corporate governance mechanisms and, in particular, of board committees and financial auditors. Corporate governance can be understood as the system through which firms are managed and controlled (Cadbury, 2000; Liao et al., 2021). It therefore has the function of balancing the well-being of all stakeholders and mitigating corporate risks (Martínez-Ferrero \& García-Sánchez, 2017b). Corporate governance consists of various mechanisms that have the function of monitoring the work of management (Aguilera et al., 2006) and ensuring the achievement of financial and nonfinancial objectives (Martínez-Ferrero \& García-Sánchez, 2017b). The corporate governance function of balancing the well-being of all stakeholders also requires the dissemination of information and its subsequent verification in order to reduce information problems such as lack of credibility (Martínez-Ferrero \& García-Sánchez, 2017b; Richardson \& Welker, 2001). This circumstance makes the link between corporate governance and assurance policies particularly strong (García-Sánchez et al., 2021a) and the analysis of the role played by board committees and by the financial auditor on the assurance of non-financial information and on the assurance provider choices particularly interesting.

To this end, in line with the literature (Al-Shaer \& Zaman, 2018), this study is based on the resource dependence theory and agency theory. In the context of companies oriented to the consideration of the non-financial aspects of management, the board performs two main functions: on the one hand, it has a control and monitoring function, examined mainly through agency theory (Cuadrado-Ballesteros et al., 2015; Hooghiemstra et al., 2019; Jensen \& Meckling, 1976; Vitolla et al., 2020a, 2020b), while on the other hand, it has a service function, which is the perspective used by resource dependence theory to explain the role of the board and its committees in achieving the objectives of a non-financial nature (Al-Shaer \& Zaman, 2018; Ben-Amar \& McIlkenny, 2015; Helfaya \& Moussa, 2017; Hillman \& Dalziel, 2003; Jizi, 2017; Mallin \& Michelon, 2011; Nam et al., 2018; Shaukat et al., 2016). The control role of the board is aimed at monitoring the actions and decisions undertaken by managers in order to protect the interests of shareholders and stakeholders (Vitolla et al., 2020a). Instead, the service role of the board refers mainly to the ability of this body to bring resources to the company through relational capital, in the form of networks of ties, and through human capital, in the form of experiences, knowledge, reputation, and skills (Chen et al., 2016a; Deng \& Yang, 2015), but also values and cultures oriented towards sustainability and transparency (Al-Shaer \& Zaman, 2018; Hillman \& Dalziel, 2003).

According to the agency theory, the board of directors represents a monitoring and control mechanism aimed at analysing and evaluating the work of managers and 
ensuring the maximization of profit for shareholders (Donnelly \& Mulcahy, 2008). It can be seen as a defence against inefficient business management (Schellenger $\&$ Wood, 1991). With reference to disclosure policies, the control exercised by the board represents a tool capable of encouraging the dissemination of information also relating to non-financial aspects. Instead, according to the resource dependence theory, the vision, values, and strategies of the board of directors represent resources of companies that can be used to obtain sustainable competitive advantages (Helfaya \& Moussa, 2017; Hillman et al., 2009; Shaukat et al., 2016) and to improve disclosure policies also relating to non-financial aspects (Al-Shaer \& Zaman, 2018; Jizi, 2017). In fact, on the one hand, this body regulates the company's sustainable agenda and the allocation of resources necessary to achieve the sustainable goals (Al-Shaer \& Zaman, 2018; Jizi, 2017) and, on the other hand, encourages a more articulated disclosure, with respect to financial information alone, to ensure greater transparency towards shareholders and stakeholders (Ben-Amar \& McIlkenny, 2015; Rowe et al., 2014; Xie \& Hayase, 2007). The experiences, knowledge, and values brought by board members become structural within the board committees. In fact, within the board, its committees represent a crucial resource in obtaining sustainable benefits and in monitoring functions, as they provide advice and skills, develop external connections, and ensure diversity of values and access to resources (Ben-Amar et al., 2017; Galbreath, 2010; Jizi, 2017; Ortiz-de-Mandojana \& Aragon-Correa, 2015; Shaukat et al., 2016). These circumstances could also affect access to assurance services. Specifically, the audit committee as the body responsible for the control and monitoring functions of a company (Raimo et al., 2021a) could directly influence the assurance services (Al-Shaer \& Zaman, 2018). In this regard, a well-designed audit committee is more likely to allocate the company's monetary resources in research and in the acquisition of external assurance for non-financial information (Al-Shaer \& Zaman, 2018). In addition, the audit committee can influence assurance services also through the relationships it has with auditing firms. In this regard, the appointment by the audit committee of a high-quality auditing firm for the assurance of the financial statement may represent an element that can also influence the assurance of non-financial information. Finally, the CSR committee also represents a resource capable of providing in-depth advice on the expectations of stakeholders, the development of sustainable strategies, and the drafting of non-financial reports, also favouring assurance services (Amran et al., 2014; Mallin \& Michelon, 2011; Shaukat et al., 2016). Furthermore, these bodies could not only affect the choice to access assurance services but could also influence assurance provider choices. In fact, the audit committee has direct responsibility for the selection and maintenance of the assurer provider (Abbott \& Parker, 2000; Braiotta, 1994). Furthermore, the financial auditor and the CSR committee could also influence the assurance provider choices. In this regard, it is reasonable to expect that these bodies will favour the choices of audit firms as assurance providers. In fact, according to the literature, assurance quality is usually higher when assurance is provided by audit firms than when provided by non-audit providers (Martínez-Ferrero et al., 2018; Ruiz-Barbadillo \& Martínez-Ferrero, 2020). The audit profession has in fact become the dominant provider in the assurance of non-financial information around the world (RuizBarbadillo \& Martínez-Ferrero, 2020). 
In detail, in this study we examine the effect of four different elements on nonfinancial information assurance practices and assurance provider choices: audit committee independence, audit committee expertise, financial auditor reputation, and CSR committee presence.

Independence is recognised internationally as an important feature of the audit committee capable of fostering monitoring functions and improving the quality and credibility of financial and non-financial disclosure (Appuhami \& Tashakor, 2017). Resource dependence theory suggests that independent directors, from a relational perspective, guarantee an external channel to improve the effectiveness of monitoring functions (Mustafa, 2018). According to Pfeffer (1972), independent members have a greater ability to understand complex environments and have more experience and knowledge to improve the monitoring function. Furthermore, the independent directors mainly bring values oriented towards ethics and are not directly focused on financial results, due to the absence of relations with inside management (Carcello \& Neal, 2003; Mangena \& Pike, 2005); therefore, they could pay particular attention to non-financial disclosure. In addition, according to the agency theory, independent members represent the best controllers of managers' actions (Fama \& Jensen, 1983). In this regard, a more independent audit committee is expected to be able to more efficiently assess internal control practices and question managers' policies and actions when necessary (Abbott et al., 2004). A more independent audit committee is also expected to detect and reduce fraudulent practices in the disclosure processes (Abbott et al., 2000; Bedard et al., 2004; Bronson et al., 2009). Therefore, it is possible to foresee that an audit committee composed of independent members emphasises the need for greater credibility and reliability of the non-financial information disclosed (Abbott et al., 2004; Al-Shaer \& Zaman, 2018; Carcello et al., 2011; Pomeroy \& Thornton, 2008; Turley \& Zaman, 2004). In this perspective, the disclosure of credible and reliable information also represents a means for independent directors to protect relationship capital and avoid litigation risk due to reporting errors (Mustafa, 2018). The attention of the audit committees composed of independent members towards the credibility of non-financial information could be substantiated not only in the search for assurance services for their own information but also in the choice of audit firms as assurance providers, given that this circumstance according to literature guarantees greater assurance quality (Martínez-Ferrero et al., 2018; Ruiz-Barbadillo \& Martínez-Ferrero, 2020). The empirical evidence in the literature has also shown beneficial effects of the audit committee independence on the level and quality of non-financial disclosure (e.g. Appuhami \& Tashakor, 2017; Raimo et al., 2021a). Therefore, it is possible to introduce the following hypotheses:

H1a Audit committee independence has a positive influence on the non-financial information assurance.

H1b Audit committee independence has a positive influence on the choice to contract an audit firm as assurance provider. 
According to the resource dependence theory, directors with specific expertise in economic-financial/accounting matters guarantee the audit committee resources that are essential for the performance of its functions (Al-Shaer \& Zaman, 2018). In addition, according to the agency theory, accounting financial expertise enhances audit committee effectiveness (Carcello et al., 2011; DeZoort et al., 2002; Krishnan \& Visvanathan, 2008; Velte, 2018). The need to include directors with financial and accounting expertise is highlighted by several regulations, such as the UK corporate governance code (FRC, 2010) and different guidelines (ASX, 2010). The rationale behind the need to include these members is that directors with no financial or accounting expertise have less chance of identifying problems and errors in disclosure processes (Agrawal \& Chadha, 2005; Appuhami \& Tashakor, 2017). On the contrary, members with financial or accounting expertise understand more easily the implications and benefits associated with good disclosure policies (Mangena \& Tauringana, 2007) and have a mind-set closer to control and audit issues. In addition, financial or accounting expertise allows these members to learn more about the functioning of capital markets and to understand the importance that investors give to the credibility and reliability of financial and non-financial information disclosed by companies (Appuhami \& Tashakor, 2017). In this perspective, investors in recent years are increasingly interested in non-financial aspects of management and the credibility and reliability of information relating to these aspects (Raimo et al., 2021b; Salvi et al., 2020, 2021). The greater effectiveness and greater knowledge of capital markets that contradict the audit committees that include members with financial expertise could lead this body to more easily recognize the importance of ensuring the credibility of the information disclosed. In this perspective, therefore, the presence of members with financial expertise could lead not only to the search for assurance services for their information but also to the selection of the best assurance providers such as audit firms (Martínez-Ferrero et al., 2018; RuizBarbadillo \& Martínez-Ferrero, 2020). The empirical evidence in the literature has also shown beneficial effects of audit committee expertise on the level and quality of disclosure (e.g. Kelton \& Yang, 2008; Mangena \& Pike, 2005). Therefore, it is possible to introduce the following hypotheses:

H2a Audit committee financial expertise has a positive influence on the non-financial information assurance.

H2b Audit committee financial expertise has a positive influence on the choice to contract an audit firm as assurance provider.

According to the resource dependence theory, the skills and knowledge of subjects external to the corporate context can represent a resource that the firm can exploit to increase its monitoring capabilities and to improve the quality and credibility of disclosure (Al-Rassas \& Kamardin, 2016; Hillman \& Dalziel, 2003). This circumstance also concerns the financial auditor who, according to the agency theory, has the important function of monitoring and bonding in the contract between shareholders and managers (Matonti et al., 2016). In this 
perspective, external monitoring mechanisms such as the most renowned auditing firms should improve the quality and credibility of the information disclosed by the company (Al-Rassas \& Kamardin, 2016). In fact, having more experts and resources at their disposal, they have an advantage over other auditing firms (AlRassas \& Kamardin, 2016). The appointment by the audit committee of highquality auditing firms for the assurance of financial statements could also have an influence on the assurance of non-financial information. In fact, the experts of auditing firms could underline the importance of assurance also of non-financial information, in light of the importance that such information has been assuming for investors in recent years. Moreover, the availability of a pool of experts could push companies to exploit these skills also for the assurance of non-financial information. Furthermore, the quality orientation of the audit committee demonstrated by the choice to rely on the best financial auditors could push this body to seek the best assurers also for non-financial information and therefore to contract an audit firm (Martínez-Ferrero et al., 2018; Ruiz-Barbadillo \& MartínezFerrero, 2020). In this regard, Fernandez-Feijoo et al. (2016) highlighted that, in an economic rationality contest, the choice of the assurer may be influenced by the selected financial auditor. In more detail, they underlined the possibility of contracting the same subject considering the possibility of exploiting economies of scope connected to the possibility of having common processes in both services, reducing the time necessary to get to know the reporting organization (Park \& Brorson, 2005) and the fees (Byus et al., 2013). Therefore, it is possible to introduce the following hypotheses:

H3a Big4 financial auditor has a positive influence on the non-financial information assurance.

H3b Big4 financial auditor has a positive influence on the choice to contract an audit firm as assurance provider.

According to the resource dependence theory, the skills and knowledge of the CSR committee improve dialogue with management about the expectations of stakeholders, favour the definition of sustainable strategies, and improve the processes of collecting and representing non-financial information (Al-Shaer \& Zaman, 2018; Amran et al., 2014; Mallin \& Michelon, 2011; Shaukat et al., 2016). In addition, in the agency theory perspective, the presence of a CSR committee increases the level of monitoring of the processes of collecting and representing non-financial information (Raimo et al., 2021a). The purpose of the CSR committee is, in fact, to plan, implement, and systematically control sustainable strategies, policies, and actions (Liao et al., 2015), also with reference to sustainability disclosure policies. Therefore, it is reasonable to expect that the knowledge, skills, and, above all, values of the members of the CSR committee will encourage attention to the quality and credibility of non-financial information. In fact, these members, on the one hand, possess knowledge and skills related to sustainability and the beneficial effects of sustainable practices and, on the other 
hand, have values oriented towards respect for the environment and the community, safeguarding and protecting relationships with stakeholders, and transparency. These circumstances could favour the use of assurance services for nonfinancial information. In addition, they could also favour the choice of audit firms as assurance provider, given that this circumstance, according to the literature, guarantees greater assurance quality (Martínez-Ferrero et al., 2018; Ruiz-Barbadillo \& Martínez-Ferrero, 2020). The empirical evidence in the literature has also shown beneficial effects of the presence of a CSR committee on the level and quality of non-financial disclosure (e.g. Liao et al., 2015; Peters \& Romi, 2014). Therefore, it is possible to introduce the following hypotheses:

H4a CSR committee presence has a positive influence on the non-financial information assurance.

H4b CSR committee presence has a positive influence on the choice to contract an audit firm as assurance provider.

\section{Research methodology}

The empirical model aimed at determining the role that the specialized committees and the Big4 financial auditor have in relation to the hiring of an assurance service for non-financial information and the choice of the assurance provider is summarized respectively in the following Eqs. 1 and 2.

$$
\begin{aligned}
& \text { dAssurance }_{i t}=\gamma_{0}+\gamma_{1} \text { AC_Indep }_{\text {it }}+\gamma_{2} \text { AC_Exp }_{\text {it }}+\gamma_{3} \text { dBig }_{\text {it }} \\
& +\gamma_{4} \mathrm{dCSRCommittee}_{\mathrm{it}}+\gamma_{5} \mathrm{dGRI}_{\mathrm{it}}+\gamma_{6} \mathrm{dIR}+\gamma_{7} \mathrm{CSR}_{\mathrm{it}} \\
& +\gamma_{8} \mathrm{~F}_{-} \text {Age }_{i t}+\gamma_{9} \mathrm{~F}_{-} \text {Size }_{i t}+\gamma_{10} \mathrm{ROA}_{\mathrm{it}}+\gamma_{11} \text { Leverage }_{\mathrm{it}} \\
& +\gamma_{12} \mathrm{IA}_{\mathrm{it}}+\gamma_{13} \mathrm{KZ} \_ \text {Index }{ }_{\mathrm{it}}+\gamma_{14} \mathrm{~N}^{\circ} \text { Analysts }_{\mathrm{it}}+\gamma_{15} \mathrm{~B} \_ \text {Size }_{\mathrm{it}} \\
& +\gamma_{16} \text { B_Activity }_{i t}+\gamma_{17} \mathrm{dCEO}_{-} \text {Duality }{ }_{\mathrm{it}}+\gamma_{18}{\mathrm{~B} \_I n d e p_{i t}} \\
& +\gamma_{19} \text { B_Women }_{\mathrm{it}}+\gamma_{20} \mathrm{NCSRPI}_{\mathrm{it}}+\gamma_{21} \mathrm{ICSRPI}_{\mathrm{it}}+\gamma_{22} \text { Year }_{\mathrm{it}}+\mu_{\mathrm{it}}+\eta_{\mathrm{i}}
\end{aligned}
$$

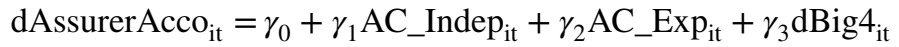

$$
\begin{aligned}
& +\gamma_{4} \mathrm{dCSRCommittee}_{\mathrm{it}}+\gamma_{5} \mathrm{dGRI}_{\mathrm{it}}+\gamma_{6} \mathrm{dIR}+\gamma_{7} \mathrm{CSR}_{\mathrm{it}} \\
& +\gamma_{8} \mathrm{~F}_{-} \text {Age }_{i t}+\gamma_{9} \mathrm{~F}_{-} \text {Size }_{i t}+\gamma_{10} \mathrm{ROA}_{\mathrm{it}}+\gamma_{11} \text { Leverage }_{i t} \\
& +\gamma_{12} \mathrm{IA}_{\mathrm{it}}+\gamma_{13} \mathrm{KZ} \_ \text {Index }_{\mathrm{it}}+\gamma_{14} \mathrm{~N}^{\circ} \text { Analysts }_{\mathrm{it}}+\gamma_{15}{\mathrm{~B} \_ \text {Size }_{\mathrm{it}}} \\
& +\gamma_{16} \text { B_Activity }_{i t}+\gamma_{17} d \text { CEO_Duality }{ }_{i t}+\gamma_{18} \text { B_Indep }_{i t} \\
& +\gamma_{19} \text { B_Women }_{i t}+\gamma_{20} \text { NCSRPI }_{\text {it }}+\gamma_{21} \text { ICSRPI }_{\text {it }} \\
& +\gamma_{22} \text { Year }_{\text {it }}+\mu_{\mathrm{it}}+\eta_{\mathrm{i}}
\end{aligned}
$$

The dependent variable dAssurance corresponds to a dummy that takes the value of 1 if the company verifies its memory of non-financial information, taking a value of 0 otherwise, reflecting the decision to provide (or not) more reliable non-financial 
information disclosures (Clarkson et al., 2019). The dependent variable dAssurerAcco is a dummy variable that takes the value 1 for those firms that have been contracted an audit firm as assurance provider, and 0 otherwise (Martínez-Ferrero et al., 2018).

In relation to the independent variables, the attributes of the audit committee are represented by AC_Indep and AC_Exp, variables that measure, respectively, the percentage of independent directors and experts in economic-financial/accounting matters that are part of this committee. These measures and operationalizations are widely used in the literature (e.g. Al-Shaer \& Zaman, 2018; Appuhami \& Tashakor, 2017; Raimo et al., 2021a). The variable dBig4 is a dummy variable that takes a value of 1 when the annual accounts are audited by Deloitte, KPMG, EY, and PwC, taking a value of 0 otherwise. Various authors defend that these four large auditors have a higher reputational risk, being strongly interested in quality services since they are more sensitive to the cost of mistakes in corporate reports of their clients [e.g. Francis \& Wang, 2008). For its part, dCSRCommittee, following authors such as García-Sánchez et al. (2019a; 2019b)], is a dummy variable that takes a value of 1 if the company has created a specialised CSR committee within the board, taking a value of 0 otherwise.

Derived from the fact that the companies present divergences in relation to the non-financial state model in format and in normalisation (García-Sánchez \& AraujoBernardo, 2020), two additional dummy variables have been considered that identify whether the statement is prepared following the guidelines of the GRI and whether it is adequate in content to the information that must be collected in an integrated report. Additionally, in order to avoid biased results, following authors such as Clarkson et al. (2019), Dalla Via and Perego (2020), and García-Sánchez (2020), we consider various control variables associated with business incentives and other control mechanisms. Table 1 shows the aspects considered, the metric used, as well as the descriptive ones and the relationship between them through the analysis of correlations.

More specifically, we include the CSR variable to control the effect that a higher commitment of firms to sustainable development may have on the hire an assurance services, similar to what was observed in the more standardized and useful information sharing (García-Sánchez et al., 2020c).

The firm incentives behind hiring an assurance service or selected and auditing firms like assurer are related to age, company size, profitability and level of indebtedness. In this sense, F_Age represents the years elapsed since the company was established. F_Size represents the size of the company calculated as the natural logarithm of total assets. The return on assets (ROA) has been considered as a variable relative to firm profitability, while indebtedness is measured by financial leverage.

Additionally, the existence of asymmetric information problems and financial restrictions will be considered following the evidence of García-Sánchez et al. (2019c). To examine the effect on informational asymmetries, following MartínezFerrero et al. (2017a), we use the precision in the forecast of future earnings for information asymmetry (IA), using the absolute value of actual earnings per share, minus median expected earnings per share, adjusted for share price as: 


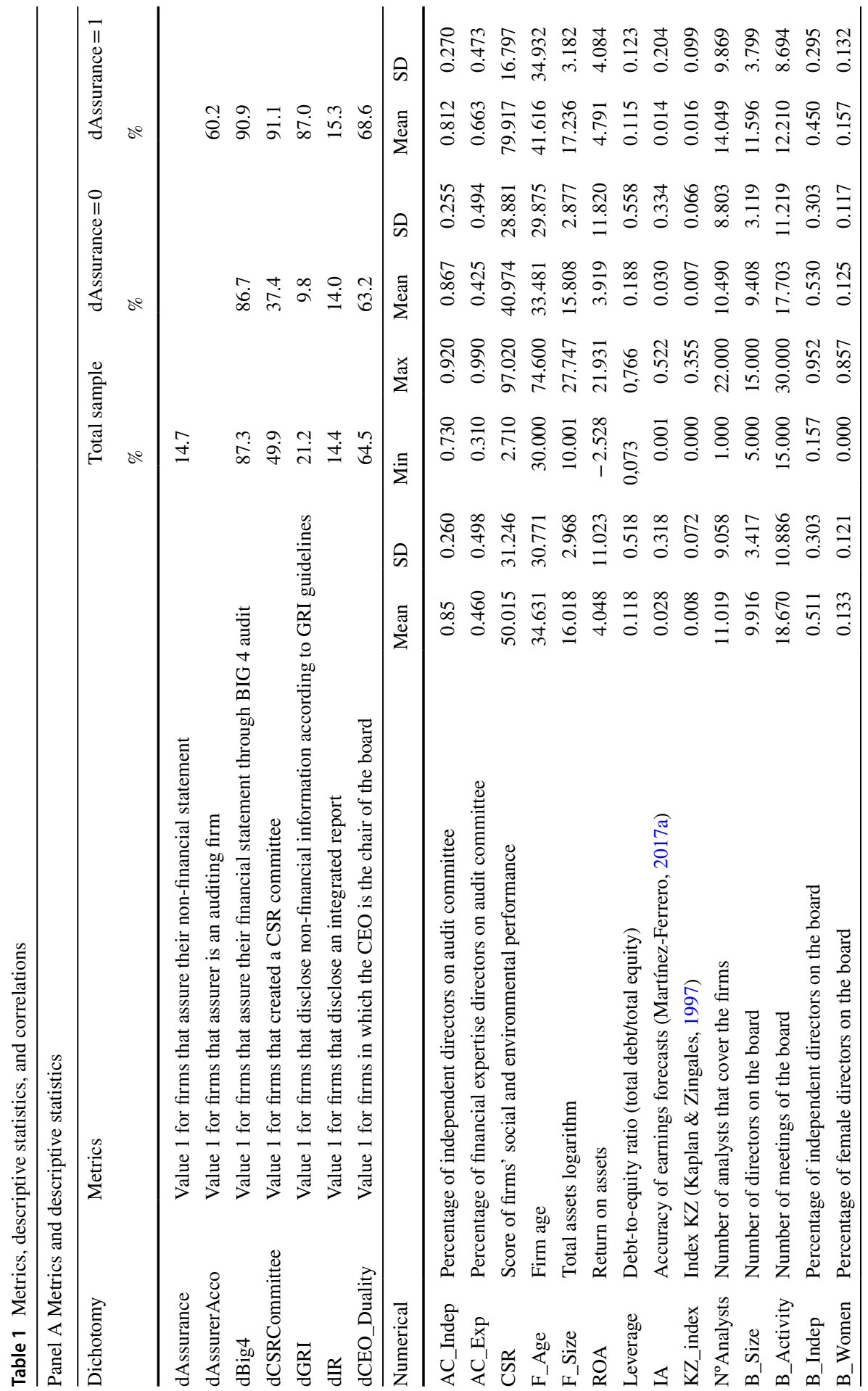




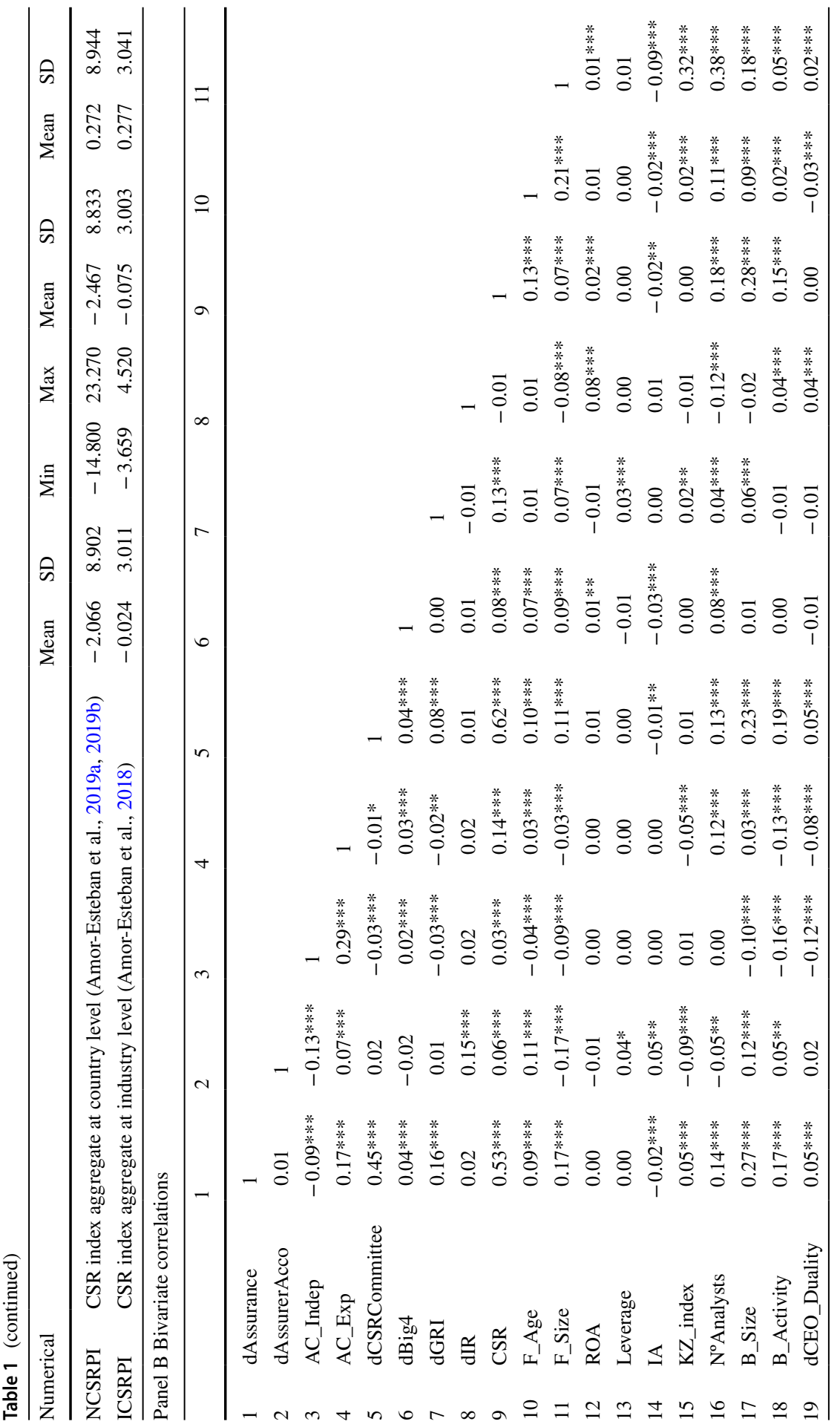




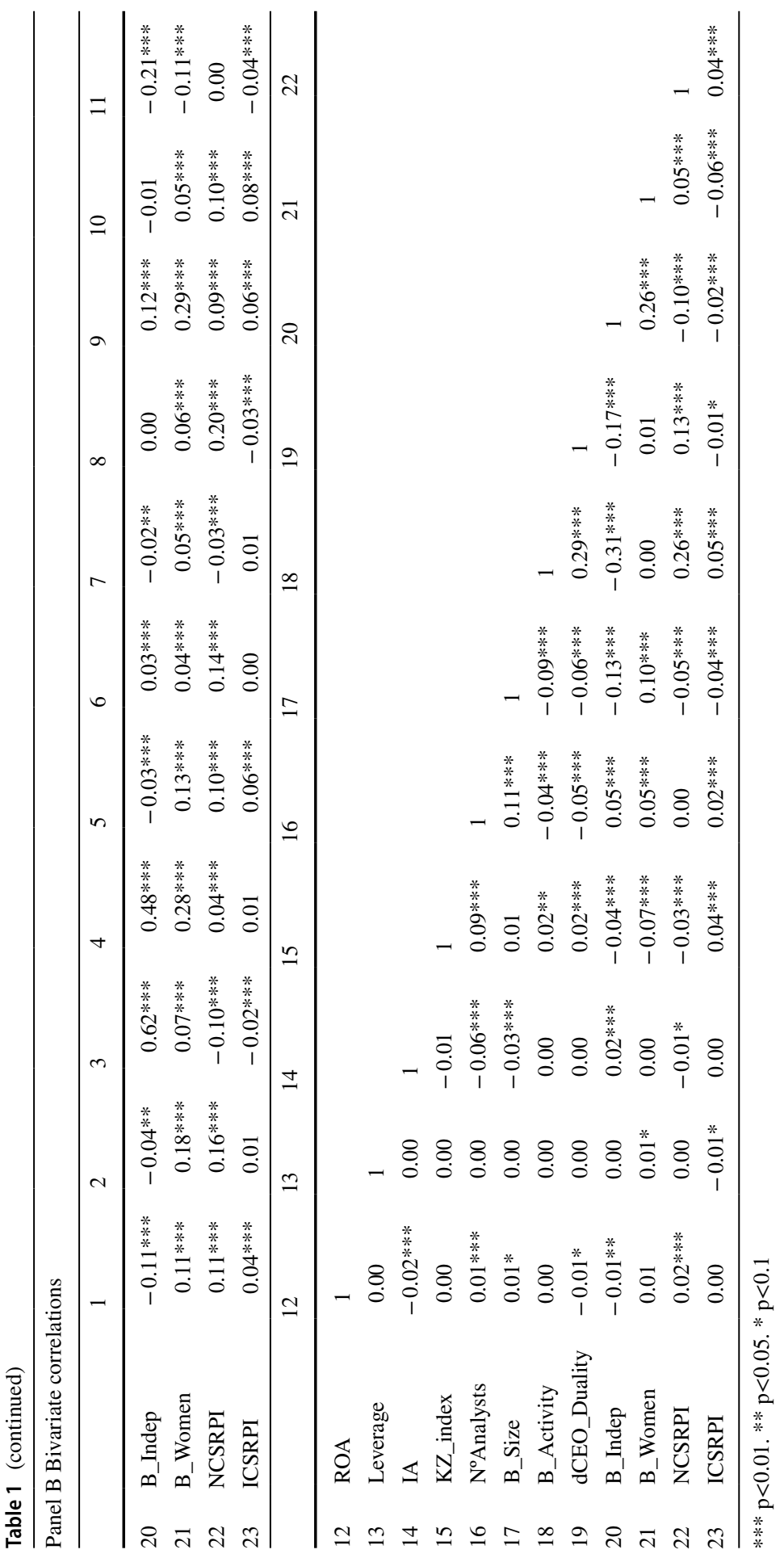




$$
\mathrm{IA}=\frac{\mid \mathrm{EPS}_{\mathrm{it}}-\text { mediana de la prediccion EPS } \mid}{\mathrm{P}_{\mathrm{it}}}
$$

where EPS, expected earnings per share of firm i in year $t$, and Pit is the price of the share of firm $i$ in year t. Lower absolute errors suggest lower level of information asymmetry due to a higher availability of information.

Based on previous literature, we use the Kaplan and Zingales's (1997) KZ index to measure financial constraints. For it, following Cheng et al. (2014), using the following procedure:

$$
\text { KZ_Index }=-1.002 \frac{\mathrm{CF}_{\mathrm{it}}}{\mathrm{A}_{\mathrm{it}-1}}-39.638 \frac{\mathrm{DIV}_{\mathrm{it}}}{\mathrm{A}_{\mathrm{it}-1}}-1.315 \frac{\mathrm{C}_{\mathrm{it}}}{\mathrm{A}_{\mathrm{it}-1}}+3.139 \mathrm{LEV}_{\mathrm{it}}+0.283 \mathrm{Q}_{\mathrm{it}}
$$

where "CF", cash flow, "A", total assets, "DIV", dividends paid, "C", cash, "LEV", leverage, and "Q", market value of equity. Higher values of these index mean that the firm support more capital restrictions.

Regarding the board of directors, according to García-Sánchez (2021), B_Activity identifies the activity of this body represented by the number of annual meetings. B_Size identifies the size of the board measured as the total number of directors. Finally, dCEO_Duality, B_Indep and B_Women represent the duality of the CEO and the independence and diversity of the board measured as the proportion of independent directors and women with respect to the total board members. The number of financial analysts who follow the company is also controlled through the variable $\mathrm{N}^{\circ}$ Analysts.

To identify the effect of institutional pressure at the country level, two numerical variables have been defined, the dynamic composite indicators NCSRPI and ICSRPI proposed by Amor-Esteban et al. (2018, 2019a) that determine the CSR commitment at country and industry level.

In order to estimate the proposed analysis model and to contrast the research hypotheses, the world-listed companies whose financial, social, and environmental information is available in the Thomson Reuters database were selected as the target population. These companies are the most active companies in terms of sustainability, presenting a greater predisposition to disclose non-financial information and hire an assurance service for it (e.g. Clarkson et al., 2019; García-Sánchez, 2020). The population consist of a maximum of 18,777 firms worldwide. Later, we have selected those firms with disclose a CSR report, with or without hiring an assurance service, guarantying a homogeneous time distribution. The final sample corresponds to 44,282 observations from 6454 companies for the period 2011-2017. These companies are headquartered in 50 countries (e.g. United States, United Kingdom, Australia, Japan, Netherland, France, Spain, etc.) and operate in 10 different industries.

The availability of a panel data sample allows the use of methodologies adapted to this information and focused on controlling the unobservable heterogeneity present in any business decision. On the other hand, the dichotomous nature of the dependent variables requires the use of discrete choice models. Together, both factors lead to the analysis technique used to estimate Eq. 1 and 2 to correspond to a logistic regression for panel data. 


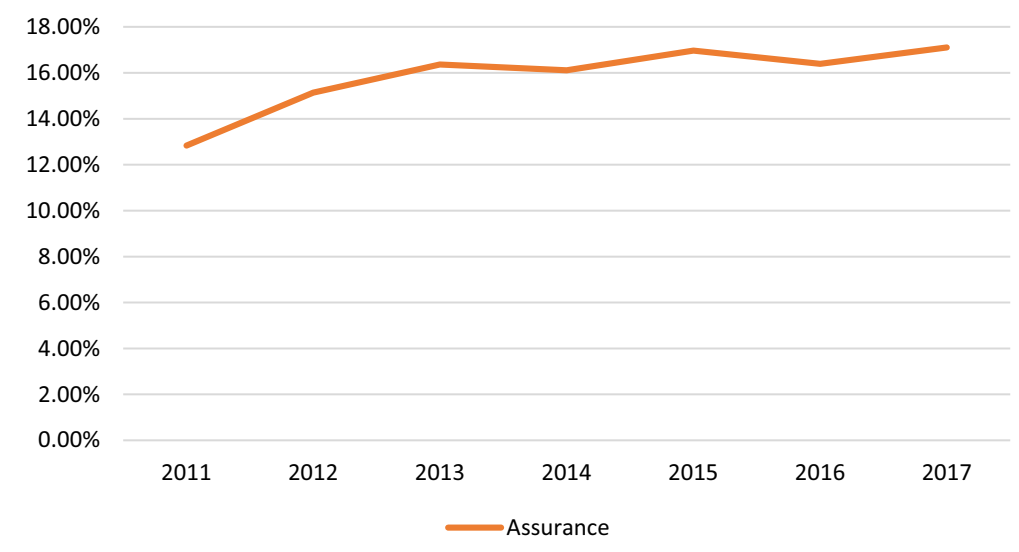

Fig. 1 Distribution by year of firms demanding non-financial assurance

\section{Results}

\subsection{Descriptive analysis}

Table 1 summarises the descriptive statistics for the variables considered in Eq. 1. Specifically, Panel A shows the metric of the different variables as well as the mean and standard deviation for the total sample and for sub-samples of companies according to whether they assure their statements of non-financial information. Panel B reflects the bivariate correlations between the variables proposed for the empirical analysis.

It can be observed that only $15 \%$ of companies assure their non-financial information statement, being prepared in $87 \%$ of the cases according to the GRI recommendations and adopting the integrated report format in only $15.3 \%$ of the companies analysed. In Fig. 1 is possible to observe additional details of the distribution by year of the number of unique firms demanding non-financial assurance.

Regarding the attributes of the audit committee, $85 \%$ of its members are independent, although only $46 \%$ have experience and training in financial/accounting matters. More than $60 \%$ of the companies analysed have a CSR committee set up within the board of directors. In relation to the business commitment to sustainability, companies that do not ensure their non-financial statements show a CSR performance below the average, while those that hire this service exceed this value by 29 points.

In relation to institutional pressures, the NCSRPI and ICSRPI dynamic composite indicators of Amor-Esteban et al. (2018, 2019a) presents a mean of -2.066 and -0.024 , suggesting that the headquarter of the firms in the sample are localized in countries and, in less manner, in industries with a lower compromise with CSR. However, when we split the sample according to firms have hire or not an assurance services, the mean value is 0.27 , suggesting that firms that have taken this decision are located in countries higher compromise with sustainability. 


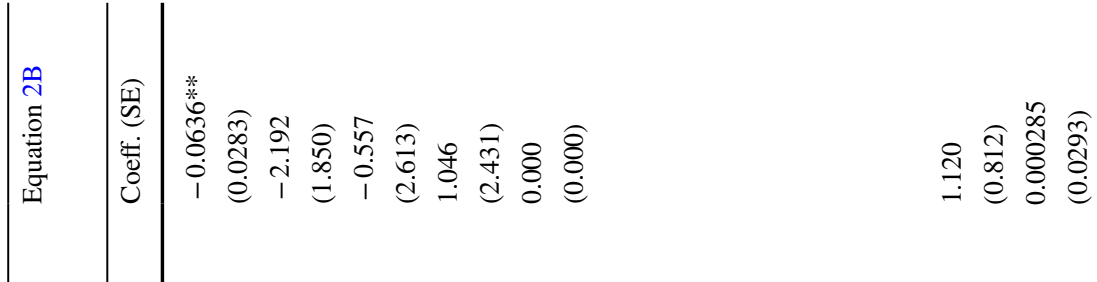

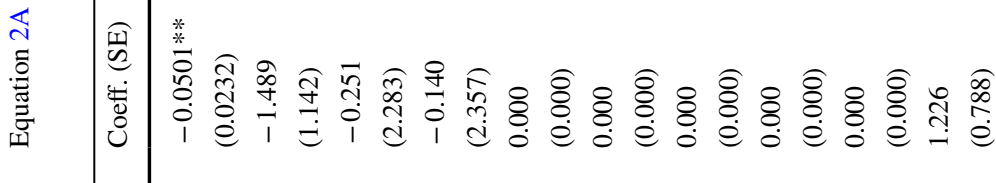

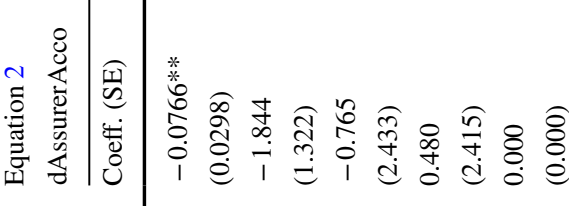

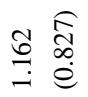

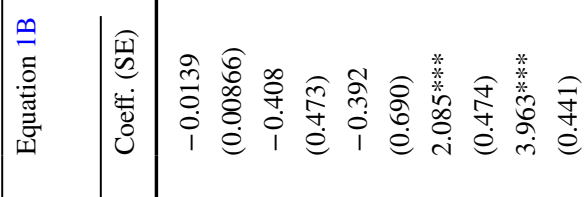

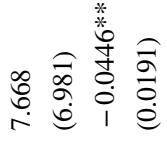

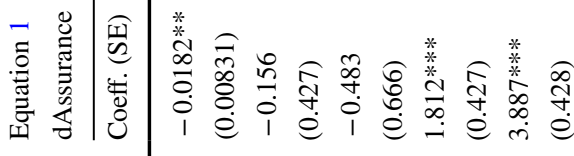

$$
\begin{aligned}
& \begin{array}{l}
\hat{a} \\
\stackrel{\partial}{+} \\
\dot{0}
\end{array}
\end{aligned}
$$

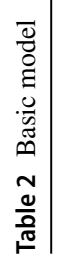

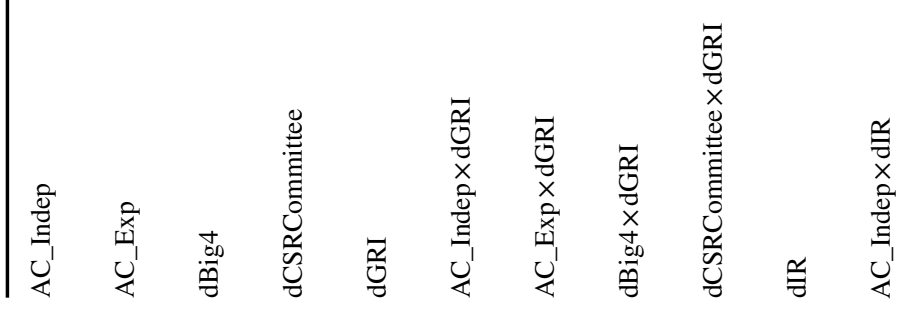




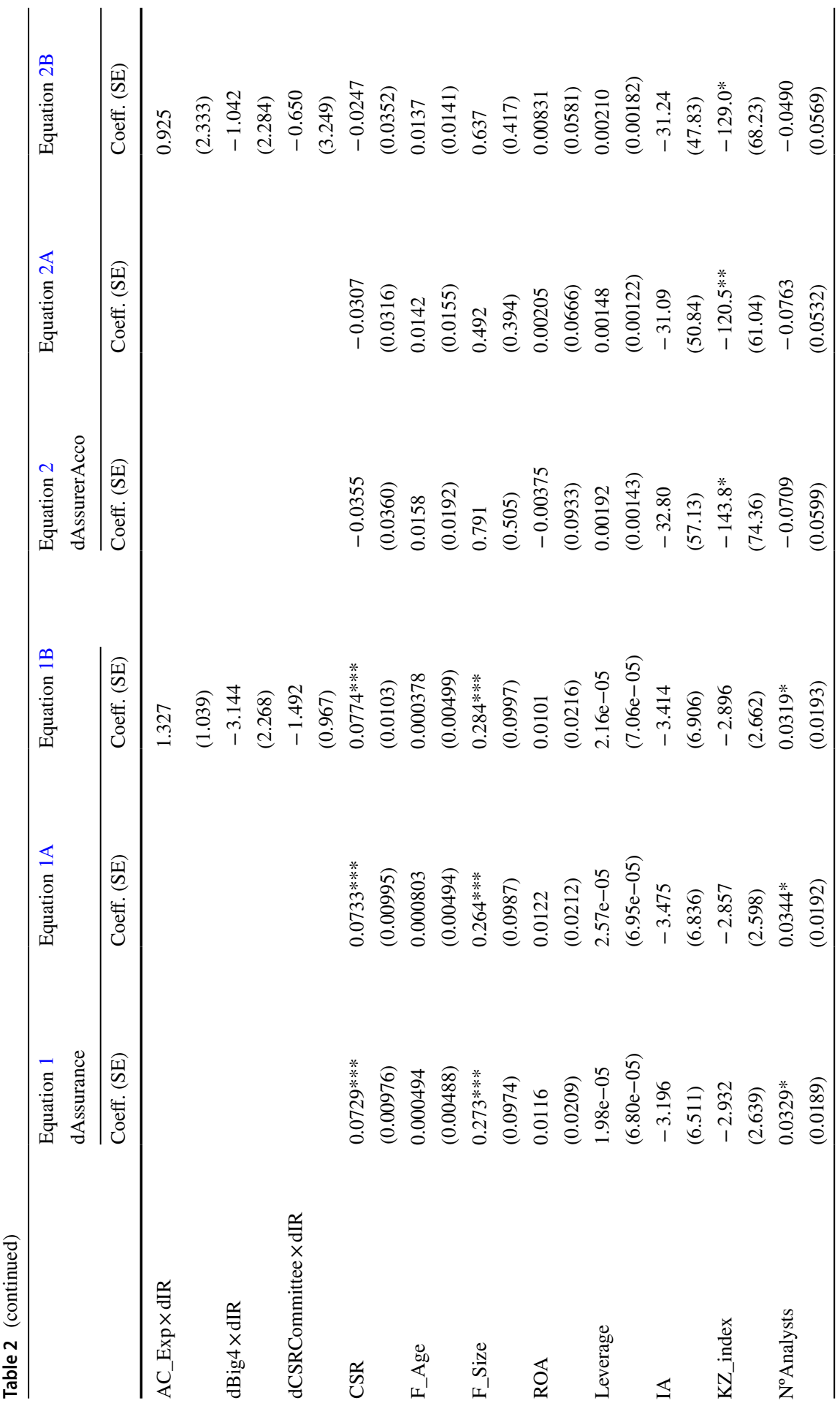




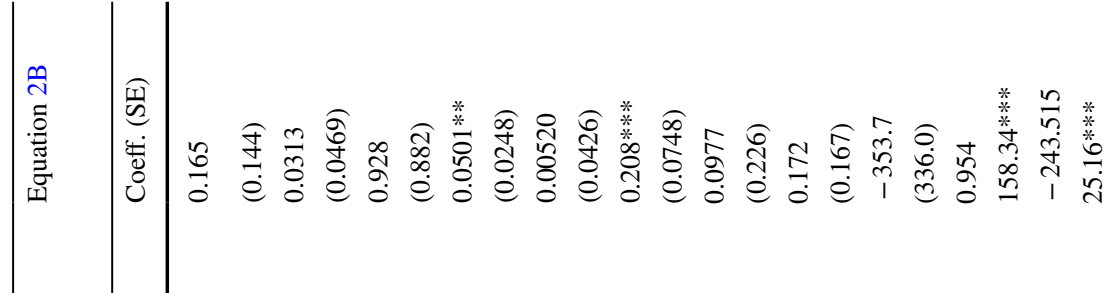

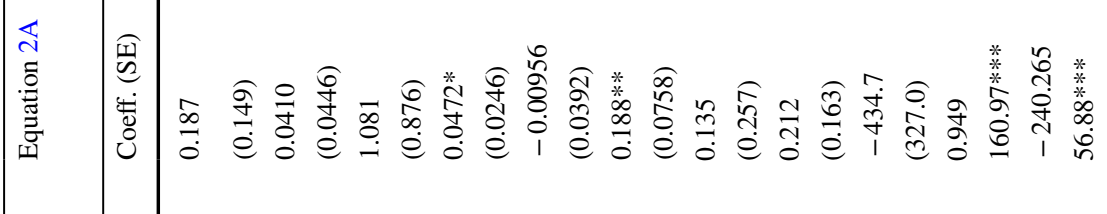

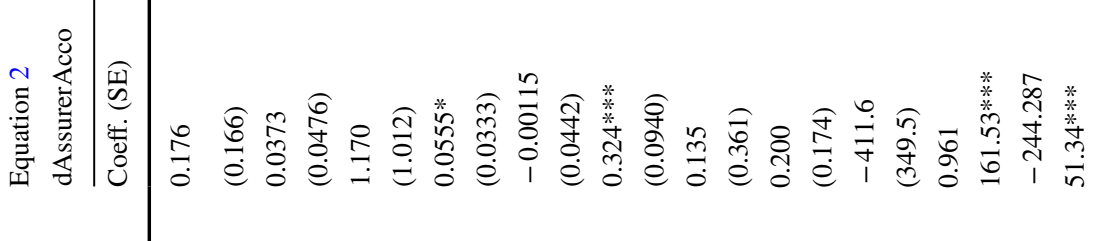

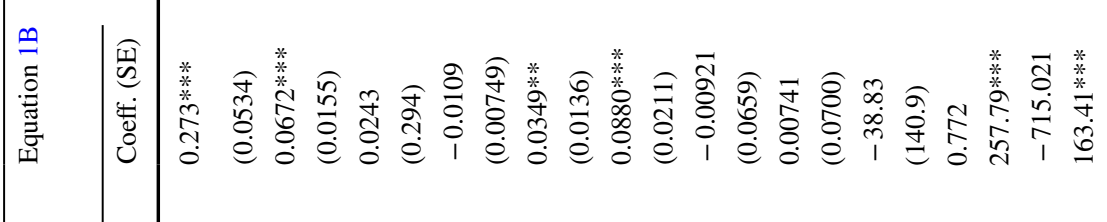

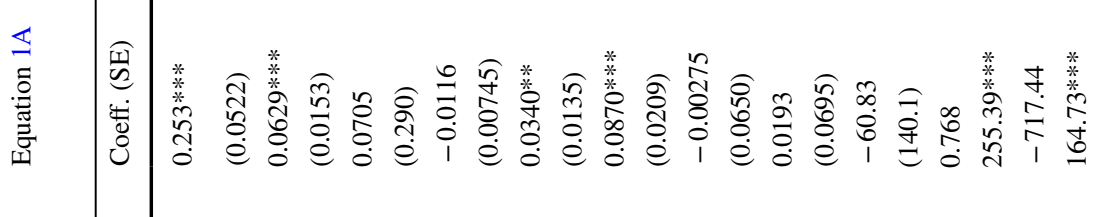

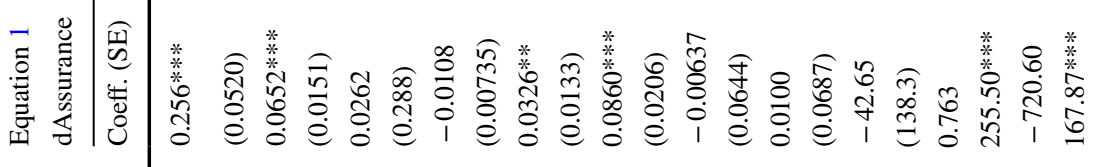

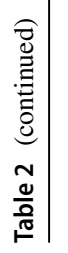

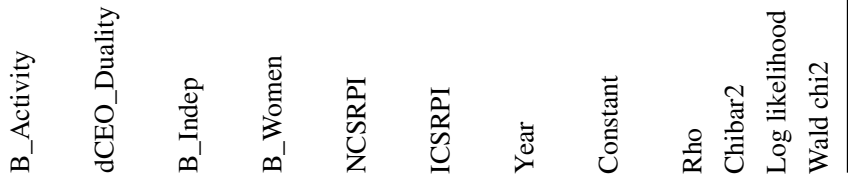




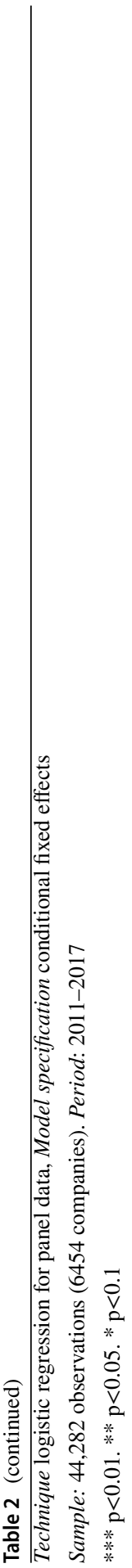




\subsection{Results of the basic model analysis}

Table 2 summarizes the results obtained for the analysis model proposed in Eqs. 1 and 2. In relation to the attributes of the audit committee, it can be observed that, contrary to expectations, the independence of the committee has a negative effect on the hiring of a non-financial information assurance service, for a confidence level of 95\% (AC_Indep: coeff. $=-0.0182$; $\mathrm{p}$ value $=0.028$ ). This result therefore does not support H1a. In addition, with respect to assurance provider choices, the results show that the independence of the audit committee negatively affects the choice to contract an audit firm as assurance provider for a confident level of 99\% (AC_Indep: coeff. $=-0.0766 ; \mathrm{p}$ value $=0.010$ ). This result therefore does not support H1b. Probably, considering that the analysed companies pay attention to sustainability and disseminate non-financial information, the fact that non-independent members work within the company allows them to have more specific resources on sustainability in terms of knowledge and skills that lead to understanding the importance of assuring non-financial information and contracting an audit firm as assurance provider. On the contrary, the independent members not having managerial roles within the company have non-specific ethical-moral values that, however, may not be directly linked to sustainability and therefore may not allow to understand the importance of assuring non-financial information and contracting an audit firm as assurance provider. In this perspective, the independent members may recognize the importance of disseminating a non-financial report, as suggested by previous studies (e.g. Appuhami \& Tashakor, 2017; Raimo et al., 2021a, but may not fully recognize the importance of ensuring credibility of the information disclosed.

In addition, the presence of directors who are experts in financial matters and accounting is not statistically significant both in relation to the hiring of a nonfinancial assurance service $\left(A C \_E x p\right.$ : coeff. $=-0.156$; $p$ value $=0.715$ ) and on the choice to contract an audit firm as assurance provider (AC_Exp: coeff. $=-1.844$; $\mathrm{p}$ value $=0.163$ ). These results therefore do not support $\mathrm{H} 2 \mathrm{a}$ and $\mathrm{H} 2 \mathrm{~b}$. It is therefore possible that financial and accounting expertise is only relevant for financial disclosure and has no significant effect on the non-financial information assurance choices. These results, albeit unexpected, confirm what Raimo et al. (2021a) highlighted in relation to the effect of the financial expertise of the audit committee on the quality of the information contained in the integrated reports.

Also the reputation of the financial auditor associated with its status as Big4 is not significant both in relation to the hiring of a non-financial assurance service $(\mathrm{dBig} 4$ : coeff. $=-0.483 ; \mathrm{p}$ value $=0.468)$ and in relation to the choice to contract an audit firm as assurance provider ( $\mathrm{dBig} 4$ : coeff. $=-0.765$; $\mathrm{p}$ value $=0.753$ ). These results do not support $\mathrm{H} 3 \mathrm{a}$ and $\mathrm{H} 3 \mathrm{~b}$. Probably, the financial auditors limit themselves to provide assurance services for financial disclosure and do not suggest to firms the extension of these services to non-financial information as well. For their part, companies probably may not fully understand the opportunity to exploit the skills and quality of the selected financial auditors also for the assurance of non-financial information. In this regard, although in an economic rationality contest the choice of the assurer is usually influenced by the selected financial auditor, corporate decisions do not always follow a rational behaviour (Fernandez-Feijoo et al., 2016). In 
fact, the choice of the assurer is sometimes influenced by other elements such as the social context (Bansal, 2005) which could also lead to the selection of a subject other than the selected financial auditor. These circumstances could therefore make the effects of the reputation of the financial auditor on the assurance of non-financial information and on the assurance provider choices not significant.

Finally, the existence of a committee specialised in CSR issues has a positive impact, significant for a $99 \%$ confidence level, in the decision to assure the statement of non-financial information (dCSRCommittee: coeff. $=1.812$; p value $=0.000$ ). This result supports $\mathrm{H} 4 \mathrm{a}$. The knowledge and skills in relation to sustainability and the beneficial effects of sustainable practices and the values oriented towards transparency and protection of the environment and stakeholders of the members of the CSR committee provide an important boost towards the use of assurance services for non-financial information. This result is in line with what emerged from previous studies which highlighted a beneficial effect of the presence of a CSR committee on the level and quality of non-financial disclosure (e.g. Liao et al., 2015; Peters \& Romi, 2014). Instead, the results show that the presence of a CSR committee is not relevant in the choice to contract an audit firm as assurance provider (dCSRCommittee: coeff. $=0.480 ; p$ value $=0.843$ ). This result therefore does not support H4b. In this perspective, the CSR committee may be interested simply in guaranteeing the assurance of its non-financial information regardless of the assurance provider.

Additionally, we observe that the variables related to the normalisation and integration of non-financial information show a divergent effect from each other. Thus, the variable that identifies the level of standardisation of this information according to the GRI recommendations has a significant positive effect for a confidence level of $99 \%$ (dGRI: coeff. $=3.887$; p-value $=0.000$ ), while the option adopting an integrated report as a disclosure model is irrelevant from the econometric point of view $(\mathrm{dIR}$ : coeff. $=0.499 ; \mathrm{p}$ value $=0.199)$.

In this sense, two complementary models were estimated to analyse the possible existence of moderating effects that the normalisation of non-financial information (Eq. 1A/2A) and the integration (Eq. 1B/2B) may have on the decisions that auditors and committees can make on the hiring of the assurance service. It should be taken into account that these two characteristics of non-financial information are predictive factors of a higher quality corporate transparency (García-Sánchez et al., 2021b), features that could correct the disinterest or opposition that the directors show, perhaps as a consequence of the reputational risks that could arise from the decision to disclose information for which they are not specialised (García-Sánchez et al., 2019a, 2019b). 


$$
\begin{aligned}
& \text { dAssurance/dAssurerAcco }{ }_{\text {it }} \\
& =\gamma_{0}+\gamma_{1} \text { AC_Indep }_{i t}+\gamma_{2} \text { AC_Exp } \text { Ex }_{\text {it }} \\
& +\gamma_{3} d \mathrm{Big}_{\mathrm{it}}+\gamma_{4} d \mathrm{CSRCommittee}_{\mathrm{it}}+\gamma_{5} d \mathrm{GRI}_{\mathrm{it}}+\gamma_{6} d \mathrm{IR} \\
& +\gamma_{7} \mathrm{CA} \_ \text {Indep } \times d \mathrm{GRI}_{\mathrm{it}}+\gamma_{8} \mathrm{CA} \_\mathrm{Exp} \times d \mathrm{GRI}_{\mathrm{it}} \\
& +\gamma_{9} d \mathrm{Big} 4 \times d \mathrm{GRI}_{\mathrm{it}}+\gamma_{10} d \mathrm{CSRCommittee} \times d \mathrm{GRI}_{\mathrm{it}}+\gamma_{11} \mathrm{CSR}_{\mathrm{it}} \\
& +\gamma_{12} \mathrm{~F}_{-} \text {Age }_{i t}+\gamma_{13} \mathrm{~F}_{-} \text {Size }_{i \mathrm{t}}+\gamma_{14} \mathrm{ROA}_{\mathrm{it}}+\gamma_{15} \text { Leverage }_{\mathrm{it}} \\
& +\gamma_{16} \mathrm{IA}_{\mathrm{it}}+\gamma_{17} \mathrm{KZ} \_ \text {Index }_{\mathrm{it}}+\gamma_{18} \mathrm{~N}^{\circ} \text { Analysts }_{\text {it }}+\gamma_{19} \mathrm{~B} \_S i z e_{\text {it }} \\
& +\gamma_{20} \text { B_Activity }_{\text {it }}+\gamma_{21} d \text { CEO_Duality }{ }_{i t}+\gamma_{22} \text { B_Indep }{ }_{i t} \\
& +\gamma_{23} \text { B_Women }_{\text {it }}+\gamma_{24} \text { NCSRPI }_{i t}+\gamma_{25} \text { ICSRPI }_{i t} \\
& +\gamma_{26} \text { Year }_{\text {it }}+\mu_{\mathrm{it}}+\eta_{\mathrm{i}}
\end{aligned}
$$

$$
\begin{aligned}
& \text { dAssurance/dAssurerAcco }{ }_{\text {it }} \\
& =\gamma_{0}+\gamma_{1} \mathrm{AC}_{-} \text {Indep }_{\mathrm{it}}+\gamma_{2} \mathrm{AC}_{-} \operatorname{Exp}_{\mathrm{it}} \\
& +\gamma_{3} \mathrm{dBig}_{\mathrm{it}}+\gamma_{4} \mathrm{dCSRCommittee}_{\mathrm{it}}+\gamma_{5} \mathrm{dGRI}_{\mathrm{it}}+\gamma_{6} \mathrm{dIR} \\
& +\gamma_{7} \mathrm{CA} \_ \text {Indep } \times \mathrm{dIR}_{\mathrm{it}}+\gamma_{8} \mathrm{CA} \_\operatorname{Exp} \times \mathrm{dIR} \mathrm{it}_{\mathrm{it}}+\gamma_{9} \mathrm{dBig} 4 \times \mathrm{dIR} \mathrm{R}_{\mathrm{it}} \\
& +\gamma_{10} \mathrm{dCSRCommittee} \times \mathrm{dIRI}_{\mathrm{it}}+\gamma_{11} \mathrm{CSR}_{\mathrm{it}}+\gamma_{12} \mathrm{~F}_{-} \mathrm{Age}_{\mathrm{it}} \\
& +\gamma_{13} \text { F_Size }_{\text {it }}+\gamma_{14} \text { ROA }_{\text {it }}+\gamma_{15} \text { Leverage }_{i t}+\gamma_{16} \text { IA }_{\text {it }} \\
& +\gamma_{17} \text { KZ_Index }_{i t}+\gamma_{18} \mathrm{~N}^{\circ} \text { Analysts }_{i t}+\gamma_{19} \mathrm{~B} \_ \text {Size }{ }_{i t} \\
& +\gamma_{20} \text { B_Activity }_{\text {it }}+\gamma_{21} d \text { CEO_Duality }{ }_{i t}+\gamma_{22} \text { B_Indep }{ }_{i t} \\
& +\gamma_{23} \text { B_Women }_{\text {it }}+\gamma_{24} \text { NCSRPI }_{i t}+\gamma_{25} \text { ICSRPI }_{i t} \\
& +\gamma_{26} \text { Year }_{\text {it }}+\mu_{\mathrm{it}}+\eta_{\mathrm{i}}
\end{aligned}
$$

In this sense, in Eq. 1A it can be observed that the results observed for Eq. 1 are maintained, further identifying that there is a moderating effect of the normalisation of non-financial information on the decisions made by the independent directors who are part of the audit committee. In this sense, it can be observed that the opposition shown by this type of directors in the event that the non-financial information is prepared in accordance with the GRI recommendations is considerably reduced ( - AC_Indep + AC_Indep $\times$ dGRI $=-0.0426+0.0312=-0.0114)$.

When we consider the moderating effect of the adoption of an integrated report, we identify possible explanations for the involvement of independent directors. In this sense, it is observed that the opposition of the independent members of the audit committee to assure the non-financial information statement occurs when it adopts the integrated report format, perhaps derived from incorporating more detailed information on risks and future forecasts, as well as by the interrelation between the key indicators provided on the different dimensions of business behaviour ( $\mathrm{AC}_{-}$ Indep $\times$ dIR: coeff. $=-0.0446 ; \mathrm{p}$ value $=0.019$ ) .

Regarding the control variables, it can be observed that the contracting of a non-financial information assurance service is more likely in companies that have an active board of directors, made up of a greater number of directors and with a greater presence of women in their ranks. Results suggest that decisions regarding 
Table 3 Robust results

\begin{tabular}{|c|c|c|c|c|}
\hline & Equation 1_RobustA & Equation 2_RobustA & Equation 1_RobustB & $\begin{array}{l}\text { Equation 2- } \\
\text { RobustB }\end{array}$ \\
\hline & dAssurance & dAssurerAcco & dAssurance & dAssurerAcco \\
\hline & Coeff & Coeff & Coeff & Coeff \\
\hline & (SE) & (SE) & $(\mathrm{SE})$ & $(\mathrm{SE})$ \\
\hline \multirow[t]{2}{*}{ AC_Indep } & $-0.0141 *$ & $-0.0487 * *$ & $-0.0141 *$ & $-0.0487 *$ \\
\hline & $(0.00847)$ & $(0.0191)$ & $(0.00847)$ & $(0.0289)$ \\
\hline \multirow[t]{2}{*}{ AC_Exp } & 0.0273 & -0.976 & 0.0273 & -0.976 \\
\hline & $(0.411)$ & $(1.037)$ & $(0.411)$ & $(1.126)$ \\
\hline \multirow[t]{2}{*}{ dBig4 } & -0.603 & 0.435 & -0.603 & 0.435 \\
\hline & $(0.683)$ & (1.827) & $(0.683)$ & $(2.952)$ \\
\hline \multirow[t]{2}{*}{ dCSRCommittee } & $1.590 * * *$ & -1.103 & $1.590 * * *$ & -1.103 \\
\hline & $(0.450)$ & $(2.019)$ & $(0.451)$ & $(3.130)$ \\
\hline \multirow[t]{2}{*}{ dGRI } & $3.983 * * *$ & 0.000 & $3.983 * * *$ & 0.000 \\
\hline & $(0.906)$ & $(0.000)$ & $(0.907)$ & $(0.000)$ \\
\hline \multirow[t]{2}{*}{ dIR } & $0.636^{*}$ & 1.311 & $0.636^{*}$ & 1.311 \\
\hline & $(0.384)$ & $(0.821)$ & $(0.384)$ & $(0.818)$ \\
\hline \multirow[t]{2}{*}{ CSR } & $0.0628 * * *$ & -0.0208 & $0.0628 * * *$ & -0.0208 \\
\hline & $(0.0108)$ & $(0.0314)$ & $(0.0109)$ & $(0.0371)$ \\
\hline \multirow[t]{2}{*}{ F_Age } & -0.000143 & 0.0196 & -0.000143 & 0.0196 \\
\hline & $(0.00483)$ & $(0.0126)$ & $(0.00483)$ & $(0.0247)$ \\
\hline \multirow[t]{2}{*}{ F_Size } & $0.187 * *$ & 0.210 & $0.187 * *$ & 0.210 \\
\hline & $(0.0949)$ & $(0.313)$ & $(0.0950)$ & $(0.663)$ \\
\hline \multirow[t]{2}{*}{ ROA } & -0.0176 & 0.000278 & -0.0176 & 0.000278 \\
\hline & $(0.0188)$ & $(0.0643)$ & $(0.0188)$ & $(0.0734)$ \\
\hline \multirow[t]{2}{*}{ Leverage } & $6.72 \mathrm{e}-05$ & 0.00144 & $6.72 \mathrm{e}-05$ & 0.00144 \\
\hline & $(0.000132)$ & $(0.00103)$ & $(0.000132)$ & $(0.00138)$ \\
\hline \multirow[t]{2}{*}{ IA } & -4.124 & -31.27 & -4.124 & -31.27 \\
\hline & $(5.905)$ & $(38.92)$ & $(5.905)$ & $(54.59)$ \\
\hline \multirow[t]{2}{*}{ KZ_index } & -3.530 & $-74.38 * *$ & -3.530 & -74.38 \\
\hline & $(2.544)$ & (31.62) & $(2.546)$ & (206.6) \\
\hline \multirow[t]{2}{*}{$\mathrm{N}^{\circ}$ Analysts } & 0.0220 & -0.0588 & 0.0220 & -0.0588 \\
\hline & $(0.0176)$ & $(0.0450)$ & $(0.0176)$ & $(0.0704)$ \\
\hline \multirow[t]{2}{*}{ B_Size } & $0.237 * * *$ & 0.107 & $0.237 * * *$ & 0.107 \\
\hline & $(0.0482)$ & (0.116) & $(0.0483)$ & $(0.153)$ \\
\hline \multirow[t]{2}{*}{ B_Activity } & $0.0662 * * *$ & 0.0500 & $0.0662 * * *$ & 0.0500 \\
\hline & $(0.0141)$ & $(0.0384)$ & $(0.0142)$ & $(0.0483)$ \\
\hline \multirow[t]{2}{*}{ dCEO_Duality } & 0.114 & 1.168 & 0.114 & 1.168 \\
\hline & $(0.279)$ & $(0.743)$ & $(0.279)$ & -1.105 \\
\hline \multirow[t]{2}{*}{ B_Indep } & -0.00646 & $0.0349 *$ & -0.00646 & 0.0349 \\
\hline & $(0.00722)$ & $(0.0203)$ & $(0.00722)$ & $(0.0330)$ \\
\hline \multirow[t]{2}{*}{ B_Women } & 0.00393 & 0.0151 & 0.00393 & 0.0151 \\
\hline & $(0.0122)$ & $(0.0313)$ & $(0.0122)$ & $(0.0374)$ \\
\hline
\end{tabular}


Table 3 (continued)

\begin{tabular}{|c|c|c|c|c|}
\hline & Equation 1_RobustA & Equation 2_RobustA & Equation 1_RobustB & $\begin{array}{l}\text { Equation 2- } \\
\text { RobustB }\end{array}$ \\
\hline & dAssurance & dAssurerAcco & dAssurance & dAssurerAcco \\
\hline & Coeff & Coeff & Coeff & Coeff \\
\hline & (SE) & $(\mathrm{SE})$ & $(\mathrm{SE})$ & $(\mathrm{SE})$ \\
\hline \multirow[t]{2}{*}{ CSRCompensation } & -0.00594 & 0.0124 & -0.00594 & 0.0124 \\
\hline & $(0.00623)$ & $(0.0165)$ & $(0.00623)$ & $(0.0169)$ \\
\hline \multirow[t]{2}{*}{ AssuCompulsory } & 0.000 & $-6.792 * *$ & 0.000 & -6.792 \\
\hline & $(0.000)$ & $(3.187)$ & $(0.000)$ & (11.39) \\
\hline \multirow[t]{2}{*}{ RepCompulsory } & 0.456 & $5.009 * * *$ & 0.456 & 5.009 \\
\hline & $(0.405)$ & $(0.986)$ & $(0.405)$ & $(5.931)$ \\
\hline \multirow[t]{2}{*}{ EnvInd } & -0.0434 & 0.0956 & -0.0434 & 0.0956 \\
\hline & $(0.239)$ & $(0.604)$ & $(0.239)$ & $(0.870)$ \\
\hline \multirow[t]{2}{*}{ Year } & 0.0043 & 0.017 & 0.0043 & 0.017 \\
\hline & $(0.069)$ & $(0.070)$ & $(0.069)$ & $(0.070)$ \\
\hline \multirow[t]{2}{*}{ Constant } & $-19.39 * * *$ & -6.138 & $-19.39 * * *$ & -6.138 \\
\hline & $(2.903)$ & $(8.413)$ & $(2.924)$ & $(12.16)$ \\
\hline Rho & 0.712 & 0.932 & 0.712 & 0.931 \\
\hline Chibar2 & $195.30 * * *$ & $160.53 * * *$ & & \\
\hline Log likelihood & -654.071 & -244.311 & -654.071 & -244.311 \\
\hline Wald chi2 & $111.19 * * *$ & $76.04 * * *$ & $108.26^{* * *}$ & $76.04 * * *$ \\
\hline
\end{tabular}

Technique: logistic regression for panel data. Model specification: conditional fixed effects (first two columns) and cluster standard error (last two columns)

Sample: 44,282 observations (6454 companies). Period: 2011-2017

$* * * \mathrm{p}<0.01$. ** $\mathrm{p}<0.05$. * $\mathrm{p}<0.1$

non-financial information are centralised in the board of directors, receiving advice from the CSR committee in cases in which this specialised committee has been constituted. Additionally, there is a greater tendency to contract this service in companies that show better social and environmental performance and those that are located in countries with a greater orientation towards protecting the interests of stakeholders. The results obtained would confirm the evidence from previous studies (e.g. Clarkson et al., 2019; Dalla Via \& Perego, 2020; García-Sánchez, 2020).

\subsection{Robustness analysis}

With the aim to evidence the robustness of the previous evidence, we control for additional factors in order to avoid bias results. In this sense, a few additional control variables have been extensively used in prior research are included in Eqs. 1 and 2: CSRCompensation-variable dummy that identify the presence of executive compensation schemes linked to sustainability targets like a driver of non-financial assurance - as well as whether a firm operates in an environmentally sensitive 
Table 4 Complementary models I

\begin{tabular}{|c|c|c|}
\hline & $\begin{array}{l}\text { Equation 1C } \\
\text { dAssurance }\end{array}$ & Equation 1D \\
\hline & Coeff. (SE) & Coeff. (SE) \\
\hline AC_Indep & $\begin{array}{l}-0.0244^{*} \\
(0.0139)\end{array}$ & $\begin{array}{l}-0.0383^{*} \\
(0.0212)\end{array}$ \\
\hline AC_Exp & $\begin{array}{l}-0.244 \\
(0.958)\end{array}$ & $\begin{array}{l}2.130 \\
(1.744)\end{array}$ \\
\hline dBig4 & $\begin{array}{l}3.206 \\
(2.032)\end{array}$ & $\begin{array}{l}-0.983 \\
(1.933)\end{array}$ \\
\hline dCSRCommittee & $\begin{array}{l}4.953 * * \\
(2.461)\end{array}$ & $\begin{array}{l}1.689 * * \\
(0.205)\end{array}$ \\
\hline dGRI & $\begin{array}{l}3.946 * * * \\
(0.437)\end{array}$ & $\begin{array}{l}4.082 * * * \\
(0.453)\end{array}$ \\
\hline dIR & $\begin{array}{l}0.488 \\
(0.390)\end{array}$ & $\begin{array}{l}0.477 \\
(0.396)\end{array}$ \\
\hline AC_Indep $\times$ dCSRCommittee & $\begin{array}{l}0.00834 \\
(0.0148)\end{array}$ & \\
\hline AC_Exp $\times$ dCSRCommittee & $\begin{array}{l}0.138 \\
(1.064)\end{array}$ & \\
\hline $\mathrm{dBig} 4 \times \mathrm{dCSRCommittee}$ & $\begin{array}{l}-4.221 * * \\
(2.098)\end{array}$ & \\
\hline AC_Indep $\times C S R$ & & $\begin{array}{l}0.000269 \\
(0.000276)\end{array}$ \\
\hline AC_Exp $\times$ CSR & & $\begin{array}{l}-0.0303 \\
(0.0224)\end{array}$ \\
\hline $\mathrm{dBig} 4 \times \mathrm{CSR}$ & & $\begin{array}{l}0.00689 \\
(0.0246)\end{array}$ \\
\hline dCSRCommittee $\times$ CSR & & $\begin{array}{l}0.0506 * * * \\
(0.0167)\end{array}$ \\
\hline CSR & $\begin{array}{l}0.0732 * * * \\
(0.00987)\end{array}$ & $\begin{array}{l}0.0374 * * \\
(0.0061)\end{array}$ \\
\hline F_Age & $\begin{array}{l}0.000528 \\
(0.00494)\end{array}$ & $\begin{array}{l}0.000323 \\
(0.00502)\end{array}$ \\
\hline F_Size & $\begin{array}{l}0.261 * * * \\
(0.0986)\end{array}$ & $\begin{array}{l}0.281 * * * \\
(0.100)\end{array}$ \\
\hline ROA & $\begin{array}{l}0.0124 \\
(0.0212)\end{array}$ & $\begin{array}{l}0.0119 \\
(0.0215)\end{array}$ \\
\hline Leverage & $\begin{array}{l}1.96 \mathrm{e}-05 \\
(6.81 \mathrm{e}-05)\end{array}$ & $\begin{array}{l}2.55 \mathrm{e}-05 \\
(6.95 \mathrm{e}-05)\end{array}$ \\
\hline IA & $\begin{array}{l}-3.729 \\
(7.051)\end{array}$ & $\begin{array}{l}-3.128 \\
(6.747)\end{array}$ \\
\hline KZ_index & $\begin{array}{l}-3.027 \\
(2.670)\end{array}$ & $\begin{array}{l}-2.931 \\
(2.738)\end{array}$ \\
\hline
\end{tabular}


Table 4 (continued)

\begin{tabular}{|c|c|c|}
\hline & \multicolumn{2}{|l|}{ dAssurance } \\
\hline & Coeff. (SE) & Coeff. (SE) \\
\hline \multirow[t]{2}{*}{$\mathrm{N}^{\circ}$ Analysts } & $0.0343^{*}$ & 0.0310 \\
\hline & $(0.0192)$ & (0.0193) \\
\hline \multirow[t]{2}{*}{ B_Size } & $0.261 * * *$ & $0.263 * * *$ \\
\hline & $(0.0529)$ & $(0.0533)$ \\
\hline \multirow[t]{2}{*}{ B_Activity } & $0.0678 * * *$ & $0.0685 * * *$ \\
\hline & $(0.0154)$ & $(0.0156)$ \\
\hline \multirow[t]{2}{*}{ dCEO_Duality } & 0.0135 & 0.0212 \\
\hline & $(0.292)$ & $(0.296)$ \\
\hline \multirow[t]{2}{*}{ B_Indep } & -0.0115 & -0.0116 \\
\hline & $(0.00743)$ & $(0.00764)$ \\
\hline \multirow[t]{2}{*}{ B_Women } & $0.0341 * *$ & $0.0311 * *$ \\
\hline & $(0.0134)$ & $(0.0136)$ \\
\hline \multirow[t]{2}{*}{ NCSRPI } & $0.0858 * * *$ & $0.0881 * * *$ \\
\hline & $(0.0209)$ & $(0.0213)$ \\
\hline \multirow[t]{2}{*}{ ICSRPI } & -0.00578 & -0.0132 \\
\hline & $(0.0651)$ & $(0.0661)$ \\
\hline \multirow[t]{2}{*}{ Year } & 0.00431 & 0.0168 \\
\hline & $(0.0694)$ & $(0.0701)$ \\
\hline \multirow[t]{2}{*}{ Constant } & -34.18 & -54.61 \\
\hline & (139.6) & (141.3) \\
\hline Rho & 0.768 & 0.774 \\
\hline Chibar2 & $253.63^{* * *} *$ & $261.54 * * *$ \\
\hline Log likelihood & -717.61 & -714.26 \\
\hline Wald chi2 & $165.31 * * *$ & $165.42 * * *$ \\
\hline
\end{tabular}

Technique: logistic regression for panel data. Model specification: conditional fixed effects

Sample: 44,282 observations (6454 companies). Period: 2011-2017 $* * * \mathrm{p}<0.01$. ** $\mathrm{p}<0.05$. * $\mathrm{p}<0.1$

industry, variable EnvInd. This variable has been obtained from Amor-Esteban et al. (2019b), who create an ordinal industry ranking according to environmental impact.

We also include two dummy variables, AssuCompulsory, for those countries that have been adopted mandatory sustainability assurance like Taiwan since 2015, or Italy, Spain and France below the inclusion of Directive 2014/95/EU of the European Parliament and of the Council, of October 22, 2014, within the legal system in each country (e.g. Kuo et al., 2021) and RepCompulsory, for those countries that have been adopted mandatory sustainability reporting but not assurance.

It is possible to observe in the first two columns of Table 3 that the results obtained are quite similar to those obtain in the initial models. In addition, we take into consideration the presence of repeated observations by using clustered standard 
errors at firm level. The last two columns, include the results for previous models with this new estimation, confirming again the evidence.

The variables AssuCompulsory and RepCompulsory have, respectively, a negative and positive impact on the hiring of an accounting assurer. However, these impacts are not robust when we use clustered standard errors.

\subsection{Complementary analysis I}

In this line, according to the results obtained, it seems relevant to analyse the possible existence of a moderating effect of CSR performance on the attributes of the audit committee and the financial auditor, as well as on the existence of a CSR committee. Likewise, it seems pertinent to analyse the possible existence of a substitute or complementary relationship between those responsible for non-financial information and the CSR committee.

According to Oh et al. (2018), corporate governance mechanisms do not function independently because they are effectively configured in bundles. In this sense, simultaneous activation of the governance mechanism that can be considered in this paper can determine the firms' decisions relating to hire an assurance service and to contract an audit firm like an assurer due to they interact with each other. In this sense, García-Sánchez et al. (2021b) argument that bundles in two distinct ways: in a complementarity or synergistic manner that suppose that the increase in the level of one mechanism marginally increases the marginal effect of another mechanism on the outcome; and in a substitution form in which both mechanisms repel each other and are better off to work individually. To empirically analyse the 'joint effect' of the proposed mechanisms, the models reflected in Eqs. 1C and 1D have been estimated.

$$
\begin{aligned}
& \text { dAssurance }_{\text {it }} \\
& =\gamma_{0}+\gamma_{1} \text { AC_Indep }_{\text {it }}+\gamma_{2} \text { AC_Exp }_{\text {it }}+\gamma_{3} \mathrm{dBig}_{\mathrm{it}} \\
& +\gamma_{4} \mathrm{dCSRCommittee}_{\text {it }}+\gamma_{5} \mathrm{dGRI}_{\mathrm{it}}+\gamma_{6} \mathrm{dIR} \\
& +\gamma_{7} \text { CA_Indep } \times \mathrm{dCSRCommittee}_{i t}+\gamma_{8} \mathrm{CA} \text { _Exp } \times \mathrm{dCSRCommitte}_{i t} \\
& +\gamma_{9} \mathrm{dBig} 4 \times \mathrm{dCSRCommitte}_{i \mathrm{it}}+\gamma_{10} \mathrm{CSR}_{\mathrm{it}}+\gamma_{11} \mathrm{~F}_{-} \mathrm{Age}_{\mathrm{it}} \\
& +\gamma_{12} \mathrm{~F}_{-} \text {Size }_{\mathrm{it}}+\gamma_{13} \mathrm{ROA}_{\mathrm{it}}+\gamma_{14} \text { Leverage }_{i \mathrm{it}}+\gamma_{15} \mathrm{IA}_{\mathrm{it}} \\
& +\gamma_{16}{\mathrm{KZ} \_I n d e x_{i t}}+\gamma_{17} \mathrm{~N}^{\circ} \text { Analysts }_{\text {it }}+\gamma_{18} \mathrm{~B} \_S i z e_{i t}+\gamma_{19} \text { B_Activity }_{\text {it }} \\
& +\gamma_{20} d \text { CEO_Duality }{ }_{i t}+\gamma_{21} \text { B_Indep }_{i t}+\gamma_{22} \text { B_Women }_{\text {it }}+\gamma_{23} \text { NCSRPI }_{\text {it }} \\
& +\gamma_{24} \mathrm{ICSRPI}_{\mathrm{it}}+\gamma_{25} \text { Year }_{\mathrm{it}}+\mu_{\mathrm{it}}+\eta_{\mathrm{i}}
\end{aligned}
$$




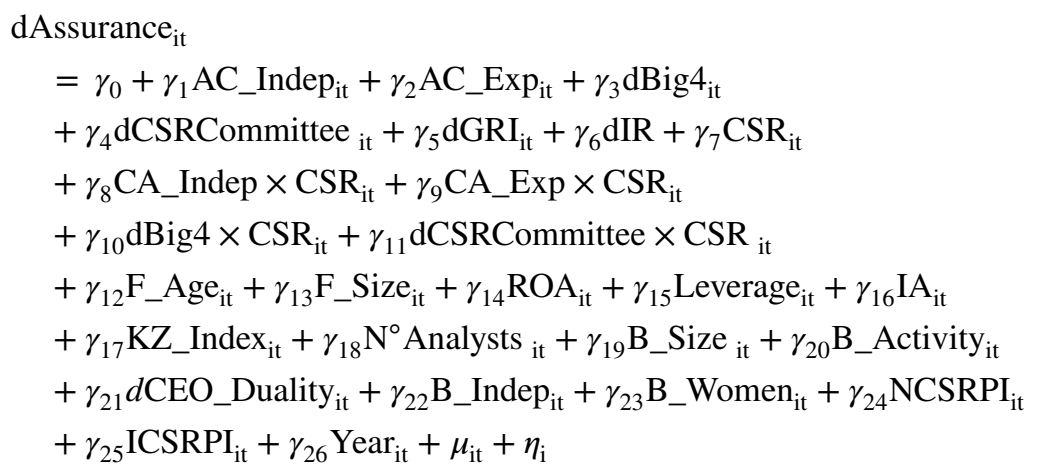

The results obtained (Table 4) show a substitute relationship between the role played by the CSR committee and the Big 4 (dBig $4 \times \mathrm{dCSRCommittee:}$ coeff. $=-4.221 ; \mathrm{p}$-value $=0.044)$, and a moderating effect that enhances the CSR performance and the existence of this specialised committee (dCSRCommittee $\times$ CSR: coeff. $=0.0506$; -value $=0.002$ ).

\subsection{Complementary analysis II}

The results obtained in the previous analysis show an opposition or disinterest of those responsible for financial information regarding the non-financial information statement, which is only slightly corrected with the inclusion of information quality attributes associated with the normalisation of it. Several authors argument that the absence of regulation on assurance services provoke that managers could establish different conditions under which these services are provided, which may or not become a symbolic sign to firms, legitimization, determining the level of credibility of the sustainability disclosures (García-Sánchez et al., 2021c, 2021d).

In this sense, one might think that the contracting conditions of the non-financial information assurance service could be moderating factors for this behaviour. In this regard, following the previous literature, those related to the scope of the service have been considered, linked to whether (i) the assurance is carried out on the entire non-financial information statement or only specific sections are verified; (ii) the work performed by the assurer reaches a reasonable level of assurance, reducing the risk of the engagement to an acceptably low level and the opinion is expressed in positive terms regarding compliance; or, if on the contrary, it corresponds to a limited level of assurance and, consequently, the conclusion of the report is expressed in negative terms. Additionally, the possible influence of the standards that the assurer will use in this work is considered, being possible a greater predisposition when it opts for the use of the ISAE300, prepared by the international federation of accountants (IFAC) (Gillet-Monjarret, 2018).

In light of this, we define three new dummy variables: Assu_EntireScope, Assu_ LevelHigh and Assu_ISAE3000. More concretely, Assu_EntireScope takes the value 1 if the assurance provider is offering assurance for the entire sustainability report, 0 if it is for just sections of the report. Assu_LevelHigh takes value 1if the 
Table 5 Complementary model II

\begin{tabular}{|c|c|c|c|}
\hline & \multicolumn{3}{|l|}{ dAssurance } \\
\hline & Coeff. (Std.error) & Coeff. (Std.error) & Coeff. (Std.error) \\
\hline AC_Indep & $\begin{array}{l}-0.0176^{* *} \\
(0.00864)\end{array}$ & $\begin{array}{l}-0.0174 * * \\
(0.00852)\end{array}$ & $\begin{array}{l}-0.0120 \\
(0.00890)\end{array}$ \\
\hline AC_Exp & $\begin{array}{l}-0.389 \\
(0.440)\end{array}$ & $\begin{array}{l}-0.416 \\
(0.447)\end{array}$ & $\begin{array}{l}-0.669 \\
(0.474)\end{array}$ \\
\hline dBig4 & $\begin{array}{l}-0.463 \\
(0.689)\end{array}$ & $\begin{array}{l}-0.693 \\
(0.676)\end{array}$ & $\begin{array}{l}-0.0859 \\
(0.732)\end{array}$ \\
\hline dCSRCommittee & $\begin{array}{l}1.760 * * * \\
(0.446)\end{array}$ & $\begin{array}{l}1.712 * * * \\
(0.434)\end{array}$ & $\begin{array}{l}1.761 * * * \\
(0.454)\end{array}$ \\
\hline dGRI & $\begin{array}{l}3.892 * * * \\
(0.433)\end{array}$ & $\begin{array}{l}3.886 * * * \\
(0.432)\end{array}$ & $\begin{array}{l}3.945 * * * \\
(0.451)\end{array}$ \\
\hline dIR & $\begin{array}{l}0.519 \\
(0.391)\end{array}$ & $\begin{array}{l}0.473 \\
(0.393)\end{array}$ & $\begin{array}{l}0.359 \\
(0.398)\end{array}$ \\
\hline Assu_EntireScope & $\begin{array}{l}-0.469 \\
(2.348)\end{array}$ & & \\
\hline AC_Indep $\times$ Assu_EntireScope & $\begin{array}{l}-0.0105 \\
(0.0186)\end{array}$ & & \\
\hline AC_Exp $\times$ Assu_EntireScope & $\begin{array}{l}1.947 \\
(1.584)\end{array}$ & & \\
\hline dBig $4 \times$ Assu_EntireScope & $\begin{array}{l}0.819 \\
(1.186)\end{array}$ & & \\
\hline dCSRCommittee $\times$ Assu_EntireScope & $\begin{array}{l}0.394 \\
(1.058)\end{array}$ & & \\
\hline Assu_LevelHigh & & $\begin{array}{l}-3.361 \\
(2.696)\end{array}$ & \\
\hline AC_Indep $\times$ Assu_LevelHigh & & $\begin{array}{l}-0.0117 \\
(0.0245)\end{array}$ & \\
\hline AC_Exp $\times$ Assu_LevelHigh & & $\begin{array}{l}2.931 * * \\
(1.320)\end{array}$ & \\
\hline dBig $4 \times$ Assu_LevelHigh & & $\begin{array}{l}2.997 \\
(1.918)\end{array}$ & \\
\hline dCSRCommittee $\times$ Assu_LevelHigh & & $\begin{array}{l}0.401 \\
(1.367)\end{array}$ & \\
\hline Assu_ISAE3000 & & & $\begin{array}{l}1.026 \\
(1.971)\end{array}$ \\
\hline AC_Indep $\times$ Assu_ISAE3000 & & & $\begin{array}{l}-0.0275 \\
(0.0265)\end{array}$ \\
\hline AC_Exp $\times$ Assu_ISAE 3000 & & & $\begin{array}{l}3.576^{* * * *} \\
(1.061)\end{array}$ \\
\hline dBig $4 \times$ Assu_ISAE 3000 & & & $\begin{array}{l}-0.744 \\
(1.417)\end{array}$ \\
\hline dCSRCommittee $\times$ ASSU_ISAE3000 & & & $\begin{array}{l}0.659 \\
(1.020)\end{array}$ \\
\hline
\end{tabular}


Table 5 (continued)

\begin{tabular}{|c|c|c|c|}
\hline & \multicolumn{3}{|l|}{ dAssurance } \\
\hline & Coeff. (Std.error) & Coeff. (Std.error) & Coeff. (Std.error) \\
\hline \multirow[t]{2}{*}{ CSR } & $0.0743 * * *$ & $0.0729 * * *$ & $0.0732 * * *$ \\
\hline & $(0.00988)$ & $(0.00979)$ & $(0.00997)$ \\
\hline \multirow[t]{2}{*}{ F_Age } & 0.00157 & 0.000552 & 0.00137 \\
\hline & $(0.00487)$ & $(0.00486)$ & $(0.00497)$ \\
\hline \multirow[t]{2}{*}{ F_Size } & $0.243 * *$ & $0.260 * * *$ & $0.242 * *$ \\
\hline & $(0.0975)$ & $(0.0969)$ & $(0.0989)$ \\
\hline \multirow[t]{2}{*}{ ROA } & 0.0126 & 0.0122 & 0.00989 \\
\hline & $(0.0209)$ & $(0.0210)$ & $(0.0214)$ \\
\hline \multirow[t]{2}{*}{ Leverage } & $2.07 \mathrm{e}-05$ & $1.89 \mathrm{e}-05$ & $1.98 \mathrm{e}-05$ \\
\hline & $(6.68 \mathrm{e}-05)$ & $(6.90 \mathrm{e}-05)$ & $(6.95 e-05)$ \\
\hline \multirow[t]{2}{*}{ IA } & -3.306 & -2.928 & -2.032 \\
\hline & $(6.759)$ & $(6.211)$ & $(4.721)$ \\
\hline \multirow[t]{2}{*}{ KZ_index } & -2.790 & -2.784 & -2.788 \\
\hline & $(2.572)$ & $(2.546)$ & $(2.543)$ \\
\hline \multirow[t]{2}{*}{$\mathrm{N}^{\circ}$ Analysts } & $0.0310^{*}$ & $0.0358^{*}$ & 0.0296 \\
\hline & $(0.0188)$ & $(0.0189)$ & $(0.0194)$ \\
\hline \multirow[t]{2}{*}{ B_Size } & $0.255^{* * *}$ & $0.253 * * *$ & $0.238 * * *$ \\
\hline & $(0.0527)$ & $(0.0524)$ & $(0.0533)$ \\
\hline \multirow[t]{2}{*}{ B_Activity } & $0.0686^{* * *}$ & $0.0637 * * *$ & $0.0678^{* * *}$ \\
\hline & $(0.0154)$ & $(0.0152)$ & $(0.0156)$ \\
\hline \multirow[t]{2}{*}{ dCEO_Duality } & -0.0137 & -0.0152 & 0.0716 \\
\hline & $(0.289)$ & $(0.289)$ & $(0.295)$ \\
\hline \multirow[t]{2}{*}{ B_Indep } & -0.0103 & -0.0111 & $-0.0144 *$ \\
\hline & $(0.00735)$ & $(0.00742)$ & $(0.00758)$ \\
\hline \multirow[t]{2}{*}{ B_Women } & $0.0308 * *$ & $0.0345^{* *}$ & $0.0375 * * *$ \\
\hline & $(0.0133)$ & $(0.0134)$ & $(0.0137)$ \\
\hline \multirow[t]{2}{*}{ NCSRPI } & $0.0772 * * *$ & $0.0837 * * *$ & $0.0752 * * *$ \\
\hline & $(0.0207)$ & $(0.0206)$ & $(0.0213)$ \\
\hline \multirow[t]{2}{*}{ ICSRPI } & -0.0120 & -0.00398 & -0.0234 \\
\hline & $(0.0642)$ & $(0.0645)$ & $(0.0658)$ \\
\hline \multirow[t]{4}{*}{ Year } & 0.0192 & 0.0115 & -0.0325 \\
\hline & $(0.0690)$ & $(0.0692)$ & $(0.0711)$ \\
\hline & -60.92 & -44.93 & 42.89 \\
\hline & (139.0) & (139.4) & (143.2) \\
\hline Rho & 0.759 & 0.759 & 0.768 \\
\hline Chibar2 & $235.61 * * *$ & $237.02 * * *$ & $235.47 * * *$ \\
\hline Log likelihood & -713.25 & -712.31 & -700.77 \\
\hline Wald chi2 & $164.62 * * *$ & $166.43^{* * *}$ & $161.57 * * *$ \\
\hline
\end{tabular}

Technique: logistic regression for panel data. Model specification: conditional fixed effects

Sample: 44,282 observations (6454 companies). Period: 2011-2017

$* * * \mathrm{p}<0.01$. ** $\mathrm{p}<0.05$. * $\mathrm{p}<0.1$ 
level of assurance provided is reasonable/high, taking 0 if it is s limited/moderate. Assu_ISAE3000 takes value 1 in order to represent the use of the ISAE3000 sustainability assurance standards as subject matter criteria, 0 otherwise. We selected only this standard due to the firms adopt both ISAE3000 and AA1000 or only ISAE3000.

$$
\begin{aligned}
& \text { dAssurance }_{i t}=\gamma_{0}+\gamma_{1} \text { AC_Indep }_{i t}+\gamma_{2} \text { AC_Exp }_{i t}+\gamma_{3} \text { dBig }_{\text {it }}+\gamma_{4} \text { dCSRCommittee }_{i t}+ \\
& \gamma_{5} \mathrm{dGRI}_{\mathrm{it}}+\gamma_{6} \mathrm{dIR}+\gamma_{7} \mathrm{Assu} \_ \text {EntireScope }+\gamma_{8} \mathrm{AC} \_ \text {Indep } * \text { Assu_EntireScope }{ }_{\mathrm{it}}+\gamma_{9} \mathrm{AC} \_ \text {Exp } * \\
& \text { Assu_EntireScope }{ }_{i t}+\gamma_{10} \mathrm{dBig} 4 * \text { Assu_EntireScope }{ }_{\mathrm{it}}+\gamma_{11} \mathrm{dCSRCommittee} * \\
& \text { Assu_EntireScope }_{i t}+\gamma_{12} \mathrm{CSR}_{\mathrm{it}}+\gamma_{13} \mathrm{~F}_{-} \text {Age } \mathrm{it}_{\mathrm{it}}+\gamma_{14} \mathrm{~F}_{-} \mathrm{Size}_{\mathrm{it}}+\gamma_{15} \mathrm{ROA}_{\mathrm{it}}+\gamma_{16} \text { Leverage }_{\mathrm{it}}+
\end{aligned}
$$

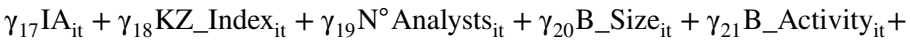

$$
\begin{aligned}
& \gamma_{22} d \text { CEO_Duality }{ }_{\text {it }}+\gamma_{23} \text { B_Indep }_{\text {it }}+\gamma_{24} \text {B_Women }_{\text {it }}+\gamma_{25} \text { NCSRPI }_{\text {it }}+\gamma_{26} \text { ICSRPI }_{\text {it }}+\gamma_{27} \text { Year }_{i t}+ \\
& \mu_{\mathrm{it}}+\eta_{\mathrm{i}}
\end{aligned}
$$

$$
\begin{aligned}
& \text { dAssurance }_{\text {it }}=\gamma_{0}+\gamma_{1} \text { AC_Indep }_{\text {it }}+\gamma_{2} \text { AC_Exp }_{\text {it }}+\gamma_{3} \mathrm{dBig}_{\mathrm{it}}+\gamma_{4} \mathrm{dCSRCommittee}_{\mathrm{it}}+ \\
& \gamma_{5} \mathrm{dGRI}_{\mathrm{it}}+\gamma_{6} \mathrm{dIR}+\gamma_{7} \mathrm{Assu} \_ \text {LevelHigh }+\gamma_{8} \mathrm{AC} \_ \text {Indep } * \text { Assu_LevelHigh }{ }_{\mathrm{it}}+\gamma_{9} \mathrm{AC} \_ \text {Exp } *
\end{aligned}
$$

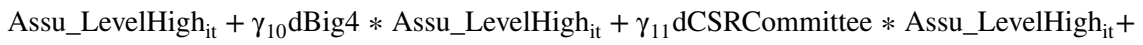

$$
\begin{aligned}
& \gamma_{12} \mathrm{CSR}_{\mathrm{it}}+\gamma_{13} \mathrm{~F}_{-} \mathrm{Age}_{\mathrm{it}}+\gamma_{14} \mathrm{~F}_{-} \mathrm{Size}_{\mathrm{it}}+\gamma_{15} \mathrm{ROA}_{\mathrm{it}}+\gamma_{16} \text { Leverage }_{\mathrm{it}}+\gamma_{17} \mathrm{IA}_{\mathrm{it}}+\gamma_{18} \mathrm{KZ}_{-} \text {Index }_{\mathrm{it}}+
\end{aligned}
$$

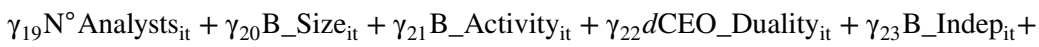

$$
\begin{aligned}
& \gamma_{24} \text { B_Women }_{\text {it }}+\gamma_{25} \text { NCSRPI }_{i t}+\gamma_{26} \text { ICSRPI }_{i t}+\gamma_{27} \text { Year }_{\text {it }}+\mu_{\text {it }}+\eta_{\mathrm{i}}
\end{aligned}
$$

$$
\begin{aligned}
& \text { dAssurance }_{i t}=\gamma_{0}+\gamma_{1} \text { AC_Indep }_{i t}+\gamma_{2} \text { AC_Exp }_{i t}+\gamma_{3} \mathrm{dBig}_{\mathrm{it}}+\gamma_{4} \mathrm{dCSRCommittee}_{\mathrm{it}}+ \\
& \gamma_{5} \mathrm{dGRI}_{\mathrm{it}}+\gamma_{6} \mathrm{dIR}+\gamma_{7} \mathrm{Assu} \_ \text {ISAE3000 }+\gamma_{8} \mathrm{AC} \_ \text {Indep } * \text { Assu_ISAE3000 }{ }_{\mathrm{it}}+\gamma_{9} \mathrm{AC} \_ \text {Exp } * \\
& \text { Assu_ISAE } 3000_{\mathrm{it}}+\gamma_{10} \mathrm{dBig} 4 * \text { Assu_ISAE3000 }{ }_{\mathrm{it}}+\gamma_{11} \mathrm{dCSRCommittee} * \text { Assu_ISAE3000 }{ }_{\mathrm{it}}+ \\
& \gamma_{12} \mathrm{CSR}_{\mathrm{it}}+\gamma_{13} \mathrm{~F}_{-} \mathrm{Age}_{\mathrm{it}}+\gamma_{14} \mathrm{~F}_{-} \mathrm{Size}_{\mathrm{it}}+\gamma_{15} \mathrm{ROA}_{\mathrm{it}}+\gamma_{16} \text { Leverage }_{\mathrm{it}}+\gamma_{17} \mathrm{IA}_{\mathrm{it}}+\gamma_{18} \mathrm{KZ}_{-} \text {Index }_{\mathrm{it}}+ \\
& \gamma_{19} \mathrm{~N}^{\circ} \text { Analysts }_{\mathrm{it}}+\gamma_{20} \mathrm{~B}_{-} \text {Size }_{\mathrm{it}}+\gamma_{21} \text { B_Activity }{ }_{\mathrm{it}}+\gamma_{22} d \mathrm{CEO} \_ \text {Duality }{ }_{\mathrm{it}}+\gamma_{23} \mathrm{~B}_{-} \text {Indep }_{\mathrm{it}}+ \\
& \gamma_{24} \mathrm{~B}_{-} \text {Women }_{\text {it }}+\gamma_{25} \mathrm{NCSRPI}_{\mathrm{it}}+\gamma_{26} \mathrm{ICSRPI}_{\mathrm{it}}+\gamma_{27} \text { Year }_{\text {it }}+\mu_{\mathrm{it}}+\eta_{\mathrm{i}}
\end{aligned}
$$

The results reflected in Table 5 indicate that although the effects of these factors are very limited, the contracting of a reasonable assurance service and the use of the ISAE3000 standard by the assurer moderate the effect that the specialised directors in financial and accounting matters show in relation to the hiring of the non-financial information assurance service. Specifically, the relevant role that both characteristics of the contracted service have on the initial predisposition of these members of the audit committee can be observed through the analysis of the coefficients and the significance of the variables AC_Exp $\times$ Assu_LevelHigh (coeff. $=2.931 ; \mathrm{p}$ value $=0.026)$ and AC_Exp $\times$ Assu_ISAE3000 (coeff. $=3.576$; p value $=0.001)$. 


\section{Conclusions}

One of the firms' incentives to assure non-financial information is to increase the transparency and credibility of the disclosure, the perception of which is highly influenced by the level of guarantee issued by the provider. Assessment, in general, can only be determined by the content of the assurance report, the only visible part of the verification process. In this sense, the use of professional assurance guidelines and the level of standardisation of the information issued are also determining factors in judging the quality of assurance work.

However, while we recognise the value and relevance of these parameters, due to the absence of generally accepted safety standards, the nature and content of the assurance statements may vary significantly. This situation generates uncertainty about the quality of the professional opinions, limiting the usefulness of this service as a credibility tool. Thus, it is important to know which bodies promote and how they design the contracted service that determines the assurance process to reduce information asymmetry. The credibility of the assurance process depends on it.

This study, based on the resource dependence theory and agency theory, analysed the role played by the main bodies responsible for the quality of financial information: the audit committee, the CSR committee, and the financial auditor. Responsible parties are all subject to risks derived from the disclosed non-financial information, whose deficiencies, if not detected in the verification process, could indirectly damage their reputation.

In this sense, the results obtained show, except for the CSR committee, a lack of interest in or opposition to hiring an assurance service, especially if it is realized by an accountant provider, except that the non-financial information is prepared according to the GRI guidelines and the contracted service is performed in accordance with the ISAE3000 standard with a reasonable level. Parameters would reflect that the assurance has been carried out with standards similar to those required for financial auditing. However, the scope of the report content is not a relevant factor in this process, perhaps due to the complexity of the information contained in one of the possible non-financial information disclosure formats, the integrated report.

The results obtained contribute to the literature confirming the postulates of the resource dependence theory and agency theory, advocating that the intrinsic knowledge and skills of the directors of the CSR committee favour relationships with stakeholders, satisfying their expectations through the disclosure of higher quality information, and increasing their credibility by hiring an assurance service. This favourable predisposition may be motivated by their specialised background in social and environmental issues. Along the same lines, perhaps, the economic-financial training of the directors in the audit committee and the Big4 could be the main reasons why these actors only support the contracting of services whose procedural requirements are comparable to the financial audit. In this sense, it must be taken into account that the accounting experts do not have the same knowledge of the members of CSR committee on social and environmental impacts. This circumstance could lead them to adopt a more conservative and critical perspective in the assurance process. 
From a practical point of view, the evidence obtained allows a more in-depth understanding of the internal processes that determine the hiring of the assurance service and its quality. In this sense, the evidence obtained increases the demands that various academic studies have been making in relation to the establishment of a common framework at the international level that allows normalising the assurance of non-financial information, favouring the recognition of this professional service by the different users of corporate information.

Finally, it should be noted that this study presents a set of limitations. Firstly, it is evident that the results provided limited support for the research hypotheses. In this regard, however, this study provides the first important evidence on the effect of board committees and the reputation of the financial auditor on the decision of companies to obtain assurance of non-financial information and on assurance provider choices. Secondly, this study does not take into account the differences between countries in their corporate governance systems. More specifically, it does not consider the differences in the role and composition of the board committees related to the institutional setting. However, these limitations do not reduce the quality of this work and offers important insights for future studies. In fact, they will be able to repeat the research also considering the differences in the corporate governance systems of the various countries by subdividing the sample into sub-samples. Besides, future studies could investigate the conditions established in the contracting of the assurance and the requirements for the provider, mainly, determining the impact that both issues have for information readability and users' decision making. Also, it is necessary to deepen the knowledge of the effect that the assurer attributes-independence, tenure, specialization and reputation-have over contracted conditions (standard, level and scope of the assurance services).

Funding Open Access funding provided thanks to the CRUE-CSIC agreement with Springer Nature. Ministerio de Ciencia, Innovación y Universidades [Grant/Award No. RTI2018-093423-B-I00]; and Universidad de Salamanca [Grant/Award No. USAL2017-DISAQ] Junta de Castilla y León y Fondo Europeo de Desarrollo Regional [Grant/Award No. CLU-2019-03 Unidad de Excelencia “Gestión Económica para la Sostenibilidad" (GECOS)].

Open Access This article is licensed under a Creative Commons Attribution 4.0 International License, which permits use, sharing, adaptation, distribution and reproduction in any medium or format, as long as you give appropriate credit to the original author(s) and the source, provide a link to the Creative Commons licence, and indicate if changes were made. The images or other third party material in this article are included in the article's Creative Commons licence, unless indicated otherwise in a credit line to the material. If material is not included in the article's Creative Commons licence and your intended use is not permitted by statutory regulation or exceeds the permitted use, you will need to obtain permission directly from the copyright holder. To view a copy of this licence, visit http://creativecommons.org/licen ses/by/4.0/. 


\section{References}

Abbott, L. J., \& Parker, S. (2000). Auditor selection and audit committee characteristics. Auditing, 19(2), 47-66.

Abbott, L. J., Parker, S., \& Peters, G. F. (2004). Audit committee characteristics and restatements. Auditing, 23(1), 69-87.

Adams, C. A., \& Evans, R. (2004). Accountability, completeness, credibility and the audit expectations gap. Journal of Corporate Citizenship, 14, 97-115.

Agrawal, A., \& Chadha, S. (2005). Corporate governance and accounting scandals. The Journal of Law and Economics, 48(2), 371-406.

Aguilera, R. V., Williams, C. A., Conley, J. M., \& Rupp, D. E. (2006). Corporate governance and social responsibility: A comparative analysis of the UK and the US. Corporate Governance, 14(3), 147-158.

Al-Rassas, A. H., \& Kamardin, H. (2016). Earnings quality and audit attributes in high concentrated ownership market. Corporate Governance, 16(2), 377-399.

Al-Shaer, H., \& Zaman, M. (2018). Credibility of sustainability reports: The contribution of audit committees. Business Strategy and the Environment, 27(7), 973-986.

Amor-Esteban, V., Galindo-Villardón, M. P., \& García-Sánchez, I. M. (2018). Useful information for stakeholder engagement: A multivariate proposal of an industrial corporate social responsibility practices index. Sustainable Development, 26(6), 620-637.

Amor-Esteban, V., Galindo-Villardón, M. P., \& García-Sánchez, I. M. (2019a). A multivariate proposal for a national corporate social responsibility practices index (NCSRPI) for international settings. Social Indicators Research, 143(2), 525-560.

Amor-Esteban, V., Galindo-Villardón, M.-P., García-Sánchez, I.-M., \& David, F. (2019b). An extension of the industrial corporate social responsibility practices index: New information for stakeholder engagement under a multivariate approach. Corporate Social Responsibility and Environmental Management, 26, 127-140.

Amran, A., Lee, S. P., \& Devi, S. S. (2014). The influence of governance structure and strategic corporate social responsibility toward sustainability reporting quality. Business Strategy and the Environment, 23(4), 217-235.

Appuhami, R., \& Tashakor, S. (2017). The impact of audit committee characteristics on CSR disclosure: An analysis of Australian firms. Australian Accounting Review, 27(4), 400-420.

Arena, M., Azzone, G., \& Mapelli, F. (2018). What drives the evolution of corporate social responsibility strategies? An institutional logics perspective. Journal of Cleaner Production, 171, 345-355.

ASX. (2010). ASX corporate governance council corporate governance principles and recommendations.

Baalouch, F., Ayadi, S. D., \& Hussainey, K. (2019). A study of the determinants of environmental disclosure quality: Evidence from French listed companies. Journal of Management and Governance, 23(4), 939-971.

Bansal, P. (2005). Evolving sustainably: A longitudinal study of corporate sustainable development. Strategic Management Journal, 26(3), 197-218.

Beasley, M. S., \& Petroni, K. R. (2001). Board independence and audit-firm type. Auditing, 20(1), 97-114.

Bedard, J., Chtourou, S. M., \& Courteau, L. (2004). The effect of audit committee expertise, independence, and activity on aggressive earnings management. Auditing, 23(2), 13-35.

Bedard, J., Coulombe, D., \& Courteau, L. (2000). Demand and supply of auditing in IPOs: An empirical analysis of the Québec market. International Journal of Auditing, 4(3), 227-245.

Ben-Amar, W., \& McIlkenny, P. (2015). Board effectiveness and the voluntary disclosure of climate change information. Business Strategy and the Environment, 24(8), 704-719.

Ben-Amar, W., Chang, M., \& McIlkenny, P. (2017). Board gender diversity and corporate response to sustainability initiatives: Evidence from the carbon disclosure project. Journal of Business Ethics, 142(2), 369-383.

Birkey, R. N., Michelon, G., Patten, D. M., \& Sankara, J. (2016). Does assurance on CSR reporting enhance environmental reputation? An examination in the US context. Accounting Forum, 40(3), $143-152$.

Braiotta, L. (1994). The audit committee handbook. Wiley.

Bronson, S. N., Carcello, J. V., Hollingsworth, C. W., \& Neal, T. L. (2009). Are fully independent audit committees really necessary? Journal of Accounting and Public Policy, 28(4), 265-280. 
Byus, K., Deis, D., \& Reed, A. (2013). Sustainability makes auditors see green. SAM Advanced Management Journal, 78(2), 25.

Cadbury, S. A. (2000). The corporate governance agenda. Corporate Governance, 8(1), 7-15.

Carcello, J. V., Hermanson, D. R., \& Ye, Z. (2011). Corporate governance research in accounting and auditing: Insights, practice implications, and future research directions. Auditing, 30(3), 1-31.

Carcello, J. V., \& Neal, T. L. (2003). Audit committee characteristics and auditor dismissals following "new" going-concern reports. The Accounting Review, 78(1), 95-117.

Casey, R. J., \& Grenier, J. H. (2015). Understanding and contributing to the enigma of corporate social responsibility (CSR) assurance in the United States. Auditing, 34(1), 97-130.

Chen, H. L., Hsu, W. T., \& Chang, C. Y. (2016). Independent directors' human and social capital, firm internationalization and performance implications: An integrated agency-resource dependence view. International Business Review, 25(4), 859-871.

Chen, L., Srinidhi, B., Tsang, A., \& Yu, W. (2016). Audited financial reporting and voluntary disclosure of corporate social responsibility (CSR) reports. Journal of Management Accounting Research, 28(2), 53-76.

Cheng, M. M., Green, W. J., \& Ko, J. C. W. (2014). The impact of strategic relevance and assurance of sustainability indicators on investors' decisions. Auditing: A Journal of Practice \& Theory, 34(1), $131-162$.

Cheng, M. M., Green, W. J., \& Ko, J. C. W. (2015). The impact of strategic relevance and assurance of sustainability indicators on investors' decisions. Auditing, 34(1), 131-162.

Cho, C. H., Michelon, G., Patten, D. M., \& Roberts, R. W. (2014). CSR report assurance in the USA: An empirical investigation of determinants and effects. Sustainability Accounting, Management and Policy Journal, 5(2), 130-148.

Choi, J., \& Wang, H. (2009). Stakeholder relations and the persistence of corporate financial performance. Strategic Management Journal, 30(8), 895-907.

Citron, D. B., \& Manalis, G. (2001). The international firms as new entrants to the statutory audit market: An empirical analysis of auditor selection in Greece, 1993 to 1997. European Accounting Review, 10(3), 439-459.

Clarkson, P., Li, Y., Richardson, G., \& Tsang, A. (2019). Causes and consequences of voluntary assurance of CSR reports. Accounting, Auditing \& Accountability Journal, 32(8), 2451-2474.

Cohen, J. R., \& Simnett, R. (2015). CSR and assurance services: A research agenda. Auditing, 34(1), 59-74.

Cuadrado-Ballesteros, B., Martínez-Ferrero, J., \& García-Sánchez, I. M. (2017). Mitigating information asymmetry through sustainability assurance: The role of accountants and levels of assurance. International Business Review, 26(6), 1141-1156.

Cuadrado-Ballesteros, B., Rodríguez-Ariza, L., \& García-Sánchez, I. M. (2015). The role of independent directors at family firms in relation to corporate social responsibility disclosures. International Business Review, 24(5), 890-901.

Dalla Via, N., \& Perego, P. (2020). The relative role of firm incentives, auditor specialization, and country factors as antecedents of non-financial audit quality. Auditing, 39(3), 75-104.

Dando, N., \& Swift, T. (2003). Transparency and assurance: Minding the credibility gap. Journal of Business Ethics, 44, 195-200.

Darnall, N., Seol, I., \& Sarkis, J. (2009). Perceived stakeholder influences and organizations' use of environmental audits. Accounting, Organizations and Society, 34(2), 170-187.

De Villiers, C., Naiker, V., \& Van Staden, C. J. (2011). The effect of board characteristics on firm environmental performance. Journal of Management, 37(6), 1636-1663.

DeAngelo, L. E. (1981). Auditor size and audit quality. Journal of Accounting and Economics, 3(2), 183-199.

Deegan, C., Cooper, B. J., \& Shelly, M. (2006). An investigation of TBL report assurance statements: UK and European evidence. Managerial Auditing Journal, 21(4), 329-371.

Deng, P., \& Yang, M. (2015). Cross-border mergers and acquisitions by emerging market firms: A comparative investigation. International Business Review, 24(1), 157-172.

Deng, X., Kang, J. K., \& Low, B. S. (2013). Corporate social responsibility and stakeholder value maximization: Evidence from mergers. Journal of Financial Economics, 110(1), 87-109.

DeZoort, F. T., Hermanson, D. R., Archambeault, D. S., \& Reed, S. A. (2002). Audit committee effectiveness: A synthesis of the empirical audit committee literature. Journal of Accounting Literature, $21,38-75$. 
Dhaliwal, D. S., Li, O. Z., Tsang, A., \& Yang, Y. G. (2011). Voluntary nonfinancial disclosure and the cost of equity capital: The initiation of corporate social responsibility reporting. The Accounting Review, 86(1), 59-100.

Dhaliwal, D. S., Radhakrishnan, S., Tsang, A., \& Yang, Y. G. (2012). Nonfinancial disclosure and analyst forecast accuracy: International evidence on corporate social responsibility disclosure. The Accounting Review, 87(3), 723-759.

Donnelly, R., \& Mulcahy, M. (2008). Board structure, ownership, and voluntary disclosure in Ireland. Corporate Governance, 16(5), 416-429.

Duff, A. (2009). Measuring audit quality in an era of change: An empirical investigation of UK audit market stakeholders in 2002 and 2005. Managerial Auditing Journal, 24(5), 400-422.

Dutta, S., Lawson, R., \& Marcinko, D. (2012). Paradigms for sustainable development: Implications of management theory. Corporate Social Responsibility and Environmental Management, 19(1), 1-10.

EY. (2014). The audit committee leadership summit. ViewPoints, Issue, 25.

Fama, E. F., \& Jensen, M. C. (1983). Separation of ownership and control. The Journal of Law and Economics, 26(2), 301-325.

Fernandez-Feijoo, B., Romero, S., \& Ruiz, S. (2016). The assurance market of sustainability reports: What do accounting firms do? Journal of Cleaner Production, 139, 1128-1137.

Francis, J. R., \& Wang, D. (2008). The joint effect of investor protection and Big 4 audits on earnings quality around the world. Contemporary Accounting Research, 25(1), 157-191.

FRC. (2010). The UK corporate governance code

Galbreath, J. (2010). Corporate governance practices that address climate change: An exploratory study. Business Strategy and the Environment, 19(5), 335-350.

García-Sánchez, I. M. (2020). Drivers of the CSR report assurance quality: Credibility and consistency for stakeholder engagement. Corporate Social Responsibility and Environmental Management, 27(6), 2530-2547.

García-Sánchez, I.-M. (2021). Información social corporativa y aseguramiento: El estado de la cuestión: Corporate social reporting and assurance: The state of the art. Revista De Contabilidad, 24(2), 241-269.

García-Sánchez, I. M., \& Araujo-Bernardo, C. A. (2020). What colour is the corporate social responsibility report? Structural visual rhetoric, impression management strategies, and stakeholder engagement. Corporate Social Responsibility and Environmental Management, 27(2), 1117-1142.

García-Sánchez, I. M., Gómez-Miranda, M. E., David, F., \& Rodríguez-Ariza, L. (2019a). Board independence and GRI-IFC performance standards: The mediating effect of the CSR committee. Journal of Cleaner Production, 225, 554-562.

García-Sánchez, I. M., Gómez-Miranda, M. E., David, F., \& Rodríguez-Ariza, L. (2019b). The explanatory effect of CSR committee and assurance services on the adoption of the IFC performance standards, as a means of enhancing corporate transparency. Sustainability Accounting, Management and Policy Journal, 10(5), 773-797.

García-Sánchez, I. M., Hussain, N., Martínez-Ferrero, J., \& Ruiz-Barbadillo, E. (2019). Impact of disclosure and assurance quality of corporate sustainability reports on access to finance. Corporate Social Responsibility and Environmental Management, 26(4), 832-848.

García-Sánchez, I. M., Aibar-Guzmán, B., Aibar-Guzmán, C., \& Azevedo, T. C. (2020). CEO ability and sustainability disclosures: The mediating effect of corporate social responsibility performance. Corporate Social Responsibility and Environmental Management, 27(4), 1565-1577.

García-Sánchez, I. M., Hussain, N., Khan, S. A., \& Martínez-Ferrero, J. (2021a). Assurance of corporate social responsibility reports: Examining the role of internal and external corporate governance mechanisms. Corporate Social Responsibility and Environmental Management. https:// doi.org/10.1002/csr.2186

García-Sánchez, I. M., Raimo, N., \& Vitolla, F. (2021b). CEO power and integrated reporting. Meditari Accountancy Research, 29(4), 908-942.

García-Sánchez, I. M., Aibar-Guzmán, C., \& Aibar-Guzmán, B. (2021c). What sustainability assurance services do institutional investors demand and what value do they give them? Sustainability, Accounting, Management and Policy Journal. https://doi.org/10.1108/SAMPJ-06-2020-0199

García-Sánchez, I.-M., Hussain, N., Aibar-Guzmán, C., \& Aibar-Guzmán, B. (2021d). Assurance of corporate social responsibility reports: Does it reduce decoupling practices? Business Ethics, the Environment \& Responsibility, 00, 1-21. https://doi.org/10.1111/beer.12394 
García-Sánchez, I. M., Raimo, N., Marrone, A., \& Vitolla, F. (2020). How does integrated reporting change in light of COVID-19? A Revisiting of the content of the integrated reports. Sustainability, 12(18), 7605.

Gillet-Monjarret, C. (2018). Assurance reports included in the CSR reports of French firms: A longitudinal study. Sustainability Accounting, Management and Policy Journal, 9(5), 570-594.

Green, W., Taylor, S., \& Wu, J. (2017). Determinants of greenhouse gas assurance provider choice. Meditari Accountancy Research, 25(1), 114-135.

GRI. (2013). The external assurance of sustainability reporting. Global Reporting Initiative.

Helfaya, A., \& Moussa, T. (2017). Do board's corporate social responsibility strategy and orientation influence environmental sustainability disclosure? UK evidence. Business Strategy and the Environment, 26(8), 1061-1077.

Hillman, A. J., \& Dalziel, T. (2003). Boards of directors and firm performance: Integrating agency and resource dependence perspectives. Academy of Management Review, 28(3), 383-396.

Hillman, A. J., Withers, M. C., \& Collins, B. J. (2009). Resource dependence theory: A review. Journal of Management, 35(6), 1404-1427.

Hoi, C. K., Wu, Q., \& Zhang, H. (2013). Is corporate social responsibility (CSR) associated with tax avoidance? Evidence from irresponsible CSR activities. The Accounting Review, 88(6), 2025-2059.

Hooghiemstra, R., Hermes, N., Oxelheim, L., \& Randøy, T. (2019). Strangers on the board: The impact of board internationalization on earnings management of Nordic firms. International Business Review, 28(1), 119-134.

ICAA. (2014). Guide for audit committees in Australia and New Zealand. Institute of Chartered Accountants Australia.

Jensen, M. C., \& Meckling, W. H. (1976). Theory of the firm: Managerial behavior, agency costs and ownership structure. Journal of Financial Economics, 3(4), 305-360.

Jizi, M. (2017). The influence of board composition on sustainable development disclosure. Business Strategy and the Environment, 26(5), 640-655.

Jo, H., \& Harjoto, M. A. (2012). The causal effect of corporate governance on corporate social responsibility. Journal of Business Ethics, 106(1), 53-72.

Kaplan, S. N., \& Zingales, L. (1997). Do investment-cash flow sensitivities provide useful measures of financing constraints? The quarterly journal of economics, 112(1), 169-215.

Kelton, A. S., \& Yang, Y. W. (2008). The impact of corporate governance on Internet financial reporting. Journal of Accounting and Public Policy, 27(1), 62-87.

Knechel, W. R., Niemi, L., \& Sundgren, S. (2008). Determinants of auditor choice: Evidence from a small client market. International Journal of Auditing, 12(1), 65-88.

Kolk, A., \& Perego, P. (2010). Determinants of the adoption of sustainability assurance statements: An international investigation. Business Strategy and the Environment, 19(3), 182-198.

KPMG. (2014). Global audit committee survey. KPMG Audit Committee Institute.

Krishnan, G. V., \& Visvanathan, G. (2008). Was Arthur Andersen different? Further evidence on earnings management by clients of Arthur Andersen. International Journal of Disclosure and Governance, 5(1), 36-47.

Kuo, L., Kuo, P.-W., \& Chen, C.-C. (2021). Mandatory CSR disclosure, CSR assurance, and the cost of debt capital: Evidence from Taiwan. Sustainability, 13, 1768. https://doi.org/10.3390/su130 41768

Kwon, S. (1996). The impact of competition within the client's industry on the auditor selection decision. Auditing, 15(1), 53.

Lennox, C. S., \& Park, C. W. (2007). Audit firm appointments, audit firm alumni, and audit committee independence. Contemporary Accounting Research, 24(1), 235-258.

Li, Z., Guan, F., \& Li, Z. Q. (2013). An empirical research on drivers of corporate social responsibility report attestation: Empirical evidence from Chinese listed companies. Auditing Research, 3, 102-112.

Liao, C. H., San, Z., Tsang, A., \& Yu, L. (2021). Board reforms around the world: The effect on corporate social responsibility. Corporate Governance, 29, 496.

Liao, L., Lin, T. P., \& Zhang, Y. (2018). Corporate board and corporate social responsibility assurance: Evidence from China. Journal of Business Ethics, 150(1), 211-225.

Liao, L., Luo, L., \& Tang, Q. (2015). Gender diversity, board independence, environmental committee and greenhouse gas disclosure. The British Accounting Review, 47(4), 409-424. 
Mallin, C. A., \& Michelon, G. (2011). Board reputation attributes and corporate social performance: An empirical investigation of the US best corporate citizens. Accounting and Business Research, 41(2), 119-144.

Mangena, M., \& Pike, R. (2005). The effect of audit committee shareholding, financial expertise and size on interim financial disclosures. Accounting and Business Research, 35(4), 327-349.

Mangena, M., \& Tauringana, V. (2007). Corporate compliance with non-mandatory statements of best practice: The case of the ASB statement on interim reports. European Accounting Review, 16(2), 399-427.

Martínez-Ferrero, J., \& García-Sánchez, I. M. (2017a). Coercive, normative and mimetic isomorphism as determinants of the voluntary assurance of sustainability reports. International Business Review, 26(1), 102-118.

Martínez-Ferrero, J., \& García-Sánchez, I. M. (2017b). Sustainability assurance and assurance providers: Corporate governance determinants in stakeholder-oriented countries. Journal of Management \& Organization, 23(5), 647-670.

Martínez-Ferrero, J., \& García-Sánchez, I. M. (2018). The level of sustainability assurance: The effects of brand reputation and industry specialisation of assurance providers. Journal of Business Ethics, 150(4), 971-990.

Martínez-Ferrero, J., García-Sánchez, I.-M., \& Ruiz-Barbadillo, E. (2018). The quality of sustainability assurance reports: The expertise and experience of assurance providers as determinants. Business Strategy and the Environment, 27(8), 1181-1196.

Matonti, G., Tucker, J., \& Tommasetti, A. (2016). Auditor choice in Italian non-listed firms. Managerial Auditing Journal, 31(4/5), 458-491.

Michelon, G., Patten, D. M., \& Romi, A. M. (2019). Creating legitimacy for sustainability assurance practices: Evidence from sustainability restatements. European Accounting Review, 28(2), 395-422.

Mock, T. J., Strohm, C., \& Swartz, K. M. (2007). An examination of worldwide assured sustainability reporting. Australian Accounting Review, 17(41), 67-77.

Moroney, R., Windsor, C., \& Aw, Y. T. (2012). Evidence of assurance enhancing the quality of voluntary environmental disclosures: an empirical analysis. Accounting \& Finance, 52(3), 903-939.

Mustafa, A. S., Che-Ahmad, A., \& Chandren, S. (2018). Board diversity, audit committee characteristics and audit quality: The moderating role of control-ownership wedge. Business and Economic Horizons, 14(3), 587-614.

Nam, J., Liu, X., Lioliou, E., \& Jeong, M. (2018). Do board directors affect the export propensity and export performance of Korean firms? A resource dependence perspective. International Business Review, 27(1), 269-280.

Nicolò, G., Ricciardelli, A., Raimo, N., \& Vitolla, F. (2021). Visual disclosure through integrated reporting. Management Decision. https://doi.org/10.1108/MD-01-2021-0034

Odriozola, M. D., \& Baraibar-Diez, E. (2017). Is corporate reputation associated with quality of CSR reporting? Evidence from Spain. Corporate Social Responsibility and Environmental Management, 24(2), 121-132.

O’Dwyer, B., \& Owen, D. L. (2005). Assurance statement practice in environmental, social and sustainability reporting: A critical evaluation. The British Accounting Review, 37(2), 205-229.

O’Dwyer, B., \& Owen, D. (2007). Seeking stakeholder-centric sustainability assurance: An examination of recent sustainability assurance practice. Journal of Corporate Citizenship, 25, 77-94.

Oh, W. Y., Chang, Y. K., \& Kim, T. Y. (2018). Complementary or substitutive effects? Corporate governance mechanisms and corporate social responsibility. Journal of Management, 44(7), 2716-2739.

Ortiz-de-Mandojana, N., \& Aragon-Correa, J. A. (2015). Boards and sustainability: The contingent influence of director interlocks on corporate environmental performance. Business Strategy and the Environment, 24(6), 499-517.

Park, J., \& Brorson, T. (2005). Experiences of and views on third-party assurance of corporate environmental and sustainability reports. Journal of Cleaner Production, 13(10-11), 1095-1106.

Peters, G. F., \& Romi, A. M. (2012). The effect of corporate governance on voluntary risk disclosures: Evidence from greenhouse gas emission reporting. Working Paper. University of Arkansas, Indiana University.

Peters, G. F., \& Romi, A. M. (2014). Does the voluntary adoption of corporate governance mechanisms improve environmental risk disclosures? Evidence from greenhouse gas emission accounting. Journal of Business Ethics, 125(4), 637-666.

Peters, G. F., \& Romi, A. M. (2015). The association between sustainability governance characteristics and the assurance of corporate sustainability reports. Auditing, 34(1), 163-198. 
Pfeffer, J. (1972). Size and composition of corporate boards of directors: The organization and its environment. Administrative Science Quarterly, 17(2), 218-228.

Pflugrath, G., Roebuck, P., \& Simnett, R. (2011). Impact of assurance and assurer's professional affiliation on financial analysts' assessment of credibility of corporate social responsibility information. Auditing, 30(3), 239-254.

Pomeroy, B., \& Thornton, D. B. (2008). Meta-analysis and the accounting literature: The case of audit committee independence and financial reporting quality. European Accounting Review, 17(2), $305-330$.

Pong, C. K., \& Kita, T. (2006). Influence of banks on company auditor choice: The case of Japan. International Journal of Auditing, 10(2), 87-98.

Raimo, N., Zito, M., \& Caragnano, A. (2019). Does national culture affect integrated reporting quality? A focus on GLOBE dimensions. In 9th International Symposium on Natural Resources Management, Zaječar, Serbia. pp. 383-392.

Raimo, N., Caragnano, A., Mariani, M., \& Vitolla, F. (2021). Integrated reporting quality and cost of debt financing. Journal of Applied Accounting Research. https://doi.org/10.1108/JAAR-04-2021-0097

Raimo, N., Vitolla, F., Marrone, A., \& Rubino, M. (2021). Do audit committee attributes influence integrated reporting quality? An agency theory viewpoint. Business Strategy and the Environment, 30(1), 522-534.

Raimo, N., Ricciardelli, A., Rubino, M., \& Vitolla, F. (2020). Factors affecting human capital disclosure in an integrated reporting perspective. Measuring Business Excellence, 24(4), 575-592.

Richardson, A. J., \& Welker, M. (2001). Social disclosure, financial disclosure and the cost of equity capital. Accounting, Organizations and Society, 26(7-8), 597-616.

Rowe, A. L., Nowak, M., Quaddus, M., \& Naude, M. (2014). Stakeholder engagement and sustainable corporate community investment. Business Strategy and the Environment, 23(7), 461-474.

Ruiz-Barbadillo, E., \& Martínez-Ferrero, J. (2020). Empirical analysis of the effect of the joint provision of audit and sustainability assurance services on assurance quality. Journal of Cleaner Production, 266, 121943.

Salvi, A., Raimo, N., Petruzzella, F., \& Vitolla, F. (2021). The financial consequences of human capital disclosure as part of integrated reporting. Journal of Intellectual Capital. https://doi.org/10.1108/ JIC-03-2021-0079

Salvi, A., Vitolla, F., Giakoumelou, A., Raimo, N., \& Rubino, M. (2020). Intellectual capital disclosure in integrated reports: The effect on firm value. Technological Forecasting and Social Change, 160, 120228.

Schellenger, M. H., \& Wood, D. D. (1991). The relationship between board of director composition and the pricing of stock. Journal of Economics \& Finance, 15(2), 1.

Shaukat, A., Qiu, Y., \& Trojanowski, G. (2016). Board attributes, corporate social responsibility strategy, and corporate environmental and social performance. Journal of Business Ethics, 135(3), 569-585.

Simnett, R., Nugent, M., \& Huggins, A. L. (2009). Developing an international assurance standard on greenhouse gas statements. Accounting Horizons, 23(4), 347-363.

Simnett, R., Vanstraelen, A., \& Chua, W. F. (2009). Assurance on sustainability reports: An international comparison. The Accounting Review, 84(3), 937-967.

Trotman, A. J., \& Trotman, K. T. (2015). Internal audit's role in GHG emissions and energy reporting: Evidence from audit committees, senior accountants, and internal auditors. Auditing, 34(1), 199-230.

Turley, S., \& Zaman, M. (2004). The corporate governance effects of audit committees. Journal of Management and Governance, 8(3), 305-332.

Velte, P. (2018). Is audit committee expertise connected with increased readability of integrated reports: Evidence from EU companies. Problems and Perspectives in Management, 16(2), 23-41.

Vitolla, F., Raimo, N., \& Rubino, M. (2019a). Appreciations, criticisms, determinants, and effects of integrated reporting: A systematic literature review. Corporate Social Responsibility and Environmental Management, 26(2), 518-528.

Vitolla, F., Raimo, N., Rubino, M., \& Garzoni, A. (2019b). How pressure from stakeholders affects integrated reporting quality. Corporate Social Responsibility and Environmental Management, 26(6), 1591-1606.

Vitolla, F., Raimo, N., \& Rubino, M. (2020a). Board characteristics and integrated reporting quality: An agency theory perspective. Corporate Social Responsibility and Environmental Management, 27(2), 1152-1163.

Vitolla, F., Raimo, N., Marrone, A., \& Rubino, M. (2020b). The role of board of directors in intellectual capital disclosure after the advent of integrated reporting. Corporate Social Responsibility and Environmental Management, 27(5), 2188-2200. 
Vitolla, F., Raimo, N., Rubino, M., \& Garegnani, G. M. (2021). Do cultural differences impact ethical issues? Exploring the relationship between national culture and quality of code of ethics. Journal of International Management, 27(1), 100823.

Wallage, P. (2000). Assurance on sustainability reporting: An auditor's view. Auditing, 19(s-1), 53-65.

Xie, S., \& Hayase, K. (2007). Corporate environmental performance evaluation: A measurement model and a new concept. Business Strategy and the Environment, 16(2), 148-168.

Yadav, P. L., Han, S. H., \& Rho, J. J. (2016). Impact of environmental performance on firm value for sustainable investment: Evidence from large US firms. Business Strategy and the Environment, 25(6), 402-420.

Zorio, A., García-Benau, M. A., \& Sierra, L. (2013). Sustainability development and the quality of assurance report: Empirical evidence. Business Strategy and the Environment, 22, 484-500.

Publisher's Note Springer Nature remains neutral with regard to jurisdictional claims in published maps and institutional affiliations.

Isabel-María García-Sánchez is PhD. in Economics and Business Administration by the Universidad de Salamanca (Spain). She writes for interdisciplinary indexed journals. Her research interests include sustainability, corporate governance as well as accounting. She has published top journals ranked with a high impact factor in the JCR, such as Long Range Planning, Technological Forecasting and Social Change, Journal of Business Ethics, Corporate Governance: An International Review, Business and Society, Business Ethics: the Environment and Responsibility, Journal of Banking and Finance, among others. Her research has been awarded in several congresses and international journals.

Nicola Raimo is a Research Fellow in Business Administration in the Department of Management, Finance and Technology at LUM University, Italy. His main research interests are: corporate social responsibility; non-financial disclosure; integrated reporting; intellectual capital; digitalisation. He is the author of several published articles and serves as reviewer for a number of international journals. He is also a member of Italian Society of Accounting and Business Administrations Scholars (SIDREA).

Víctor Amor-Esteban is PhD. in Estadística Multivariante Aplicada by the Universidad de Salamanca (Spain). He writes for interdisciplinary indexed journals. His research interests include corporate social responsibility, and multivariant. He has published top journals ranked with a high impact factor in the JCR, such as Ecological Indicators, Corporate Social Responsibility and Environmental Management, Social Indicator Research, Sustainable Development and Environmental Science and Pollution Research, among others. He obtain the extraordinary doctorate award by the Universidad de Salamanca.

Filippo Vitolla is a Full Professor in Business Administration at LUM University, Italy. He is a member of the Faculty of LUM University International PhD in Economics and Management of Sustainability and Innovation. He is also a member of Italian Academic Association of Business Administration (AIDEA and SIDREA). He is the author of many books, books chapters and articles/papers in national and international academic journals. 